University of Louisville

ThinkIR: The University of Louisville's Institutional Repository

Electronic Theses and Dissertations

$5-2011$

\title{
Lieb-, Lied- und Weines Trunkenheit : interrelationships in Hugo Wolf's "Schenkenbuch" Lieder.
}

Theresa Luebbers Cole

University of Louisville

Follow this and additional works at: https://ir.library.louisville.edu/etd

\section{Recommended Citation}

Cole, Theresa Luebbers, "Lieb-, Lied- und Weines Trunkenheit : interrelationships in Hugo Wolf's

"Schenkenbuch" Lieder." (2011). Electronic Theses and Dissertations. Paper 263.

https://doi.org/10.18297/etd/263

This Master's Thesis is brought to you for free and open access by ThinkIR: The University of Louisville's Institutional Repository. It has been accepted for inclusion in Electronic Theses and Dissertations by an authorized administrator of ThinkIR: The University of Louisville's Institutional Repository. This title appears here courtesy of the author, who has retained all other copyrights. For more information, please contact thinkir@louisville.edu. 


\title{
LIEB-, LIED- UND WEINES TRUNKENHEIT:
}

\section{INTERRELATIONSHIPS IN HUGO WOLF'S “SCHENKENBUCH” LIEDER}

\author{
By \\ Theresa Luebbers Cole \\ B.M., Murray State University, 2007 \\ A Thesis \\ Submitted to the Faculty of the \\ School of Music of the University of Louisville \\ in Partial Fulfillment of the Requirements \\ for the Degree of
}

Master of Music
Department of Music History
University of Louisville
Louisville, Kentucky

May 2011 



\section{LIEB-, LIED- UND WEINES TRUNKENHEIT: INTERRELATIONSHIPS IN HUGO WOLF'S “SCHENKENBUCH” LIEDER By Theresa Luebbers Cole \\ B.M., Murray State University, 2007 \\ A Thesis Approved on}

April 25, 2011

by the following Thesis Committee:

Thesis Director 


\section{ACKNOWLEDGEMENTS}

Many thanks are owed to my thesis advisor, Dr. Jean Christensen, for her guidance and insight without which this thesis could not have been completed. I am also grateful to the other members of my committee, Dr. Julia Shinnick and Dr. Anne Marie de Zeeuw, for their invaluable assistance in the construction of this thesis. Also, Dr. Alan Leidner of the University of Louisville Modern Languages Department kindly offered advice and clarification for my understanding of Goethe's poetry and the German language.

My husband Sergio didn't realize what he was getting into when he married a budding musicologist, but without his love, support and instinctive understanding of how to keep me sane I would not have gotten this far. I am also indebted to Ashley Mattingly for her sympathetic ear and technological assistance with preparing the examples.

Finally, I owe much to my parents, Gerard and Becky Luebbers, for their endless love, support and teaching me from an early age that exploration and learning are the greatest blessings of life. 


\begin{abstract}
LIEB-, LIED- UND WEINES TRUNKENHEIT:

INTERRELATIONSHIPS IN HUGO WOLF'S “SCHENKENBUCH” LIEDER

Theresa Luebbers Cole
\end{abstract}

April 25, 2011

Johann Wolfgang von Goethe's West-östlicher Divan combines the Persian influence of the fourteenth-century poet Hafiz with Goethe's own Germanic literary heritage. The result was a synthesis of symbolism and multivalent meanings that Goethe himself doubted could be effectively portrayed in a musical setting. Hugo Wolf composed seventeen songs with poems from three of the Divan's thirteen books.

Five of these songs come from "Das Schenkenbuch," an exploration of wine and intoxication as metaphors for religious experience. This thesis explores Wolf's success in addressing the complex system of meanings and references in the poems while providing suitable settings for each individual song. The result is an inter-related set of Lieder tied together through form, key and motivic elements that provide a unified exploration of the meaning of spiritual intoxication. 
TABLE OF CONTENTS

\section{PAGE}

ACKNOWLEDGEMENTS

ABSTRACT

LIST OF EXAMPLES

LIST OF TABLES

iv

vi

vii

INTRODUCTION

HUGO WOLF AND THE GOETHE-LIEDER 5

Biography of Hugo Wolf 5

Biography of Johann Wolfgang von Goethe $\quad 7$

The Goethe-Lieder 9

$\begin{array}{lr}\text { THE WEST-ÖSTLICHER DIVAN } & 12\end{array}$

The Genesis of the West-östlicher Divan 12

Structure and Style of the Divan $\quad 14$

Converging Meanings in "Das Schenkenbuch" 15

THE FIVE SONGS 19

"Ob der Koran von Ewigkeit sei?" 19

"Trunken müssen wir alle sein!" 24

"So lang man nüchtern ist" $\quad 32$

"Sie haben wegen der Trunkenheit" 38

"Was in der Schenke" 43

UNITY IN THE "SCHENKENBUCH” LIEDER 48

$\begin{array}{lr}\text { CONCLUSION } & 58\end{array}$

$\begin{array}{lr}\text { REFERENCES } & 60\end{array}$

$\begin{array}{ll}\text { CURRICULUM VITAE } & 63\end{array}$ 


\section{LIST OF EXAMPLES}

EXAMPLE

1: "Ob der Koran von Ewigkeit sei?" mm. 1-5

2: "Ob der Koran von Ewigkeit sei?" mm. 14-18

3: "Trunken müssen wir alle sein!" mm. 1-4

4: "Trunken müssen wir alle sein!" mm. 21-24

5: "Trunken müssen wir alle sein!" mm. 42-45

6: "Trunken müssen wir alle sein!" mm. 54-57

7: "So lang man nüchtern ist" mm. 20-21, 41-42

8: "So lang man nüchtern ist" mm. 1-4

9: "So lang man nüchtern ist" mm. 5-8

10: "So lang man nüchtern ist" $\mathrm{mm} .18-21$

11: "Sie haben wegen der Trunkenheit" mm. 1-2

12: "Sie haben wegen der Trunkenheit" mm. 11-12

13: "Was in der Schenke" mm. 5-8

14: "Was in der Schenke" mm. 27-30

15: "Was in der Schenke" mm. 47-50

16: "Ob der Koran von Ewigkeit sei?" mm. 1-5

17: "Trunken müssen wir alle sein!" m. 41 


\section{LIST OF TABLES}

TABLE

1: Tonal organization in "So lang man nüchtern ist"

2: Formal significance in the "Schenkenbuch" Lieder

3: Tonal design in the "Schenkenbuch" Lieder
PAGE

34

49

53 


\section{INTRODUCTION}

A half dozen new songs have already been put to bed.

Most obedient servant!

Yes, indeed! ${ }^{1}$

Overall I got the impression that I was not understood, that they were preoccupied with the musical elements alone and forgot about what is new and original in my musical-poetic concept. ${ }^{2}$

The Lieder of Hugo Wolf represent the culmination of the nineteenth-century German Art Song tradition. His dramatic declamation, independent and sometimes virtuosic piano lines, advanced chromatic language and intense sensitivity to the words and meaning of the poetry combine to create musical translations of poems. Wolf merged elements from the song legacies of Schumann and Schubert, the ballads of Loewe, the harmonic style and vocal declamation of Wagner and his own wit and humor to produce masterful Lieder.

The two letters quoted above are from Hugo Wolf to Melanie Köchert. The first (dated 19 January, 1889) is a postscript noting the composition of six poems from Goethe's West-östlicher Divan, including five from "Das Schenkenbuch." The second (dated 12 October, 1890) refers to a Munich performance of many of Wolf's GoetheLieder and at least one of the songs from "Das Schenkenbuch" that he referenced in the January, 1889 letter. Poems from the West-östlicher Divan had been not been set in any large number by previous Lieder composers (Wolf composed seventeen in all) and no

\footnotetext{
${ }^{1}$ Hugo Wolf, Letters to Melanie Köchert, trans. and ed. Louise McClelland Urban (Madison, WI: The University of Wisconsin Press, 1991), 4.

${ }^{2}$ Ibid., 19.
} 
composer other than Schumann had delved into the "Das Schenkenbuch" poems. ${ }^{3}$ Goethe himself thought the poems from the Divan were not suitable for musical settings because

every single segment is permeated with the sense of the whole, is intensely oriental, relates to customs, usages, religion, and must be explicated by a preceding poem if it is to have an effect on the imagination or emotion. I myself had not realized what a marvelous unity I had made of it. ${ }^{4}$

Wolf's approach to song composition, the "new musical-poetic concept" cited in his letter above, allowed him to bring out the rich interrelationships and symbolisms of the poetry. The aim of this thesis is to explore how the five songs from "Das Schenkenbuch" answered the stringent demands of Goethe's poetry. Ultimately, Wolf's selection of poems and adeptness at referencing multiple levels of meaning form the five "Schenkenbuch" Lieder into an interrelated group of songs that explore the nature of spiritual intoxication.

Studies and articles on Wolf emerged soon after his death, including the personal reminisces of Hermann Bahr and Ernest Newman's English biography. Newman noted that his research was limited by the unavailability of many of Wolf's personal letters and the need for prudence in areas where persons still living were concerned. The circumstances have changed in the past hundred years: by the time of Frank Walker's seminal English biography in 1952, Walker had access to most letters and documents pertaining to Wolf. Wolf's letters as well as his criticisms for the Weiner Salonblatt have since been published in German and English.

\footnotetext{
${ }^{3}$ Schumann composed the most settings other than Wolf from the Divan's poems, including two from "Das Schenkenbuch" (not the same poems as Wolf set) in Myrthen, op. 25. Carol June Bradley, Index to Poetry in Music: A Guide to the Poetry Set as Solo Songs by 125 Major Composers (New York: Routledge, 2003), 251.

${ }^{4}$ Johann Wolfgang von Goethe, Goethe-Zelter Briefwechsel I ,419, 421-22, quoted in Jack M. Stein, Poem and Music in the German Lied (Cambridge: Harvard University Press, 1971),184.
} 
In addition to primary sources, numerous studies of Wolf's life and music have been published and form a strong base for research. Newman's and Walker's biographies maintain prominence in English language sources, and Dietrich Fischer-Dieskau recently published another German biography of Wolf. Eric Sams and Susan Youens have both published comprehensive studies of Wolf's corpus of work. Sams breaks the Lieder collections down to each individual song while Youens aims towards the identification and illustration of main themes throughout Wolf's compositions. Other authors have focused on stylistic elements of Wolf's songs, including Amanda Glauert in Wolf and the Wagnerian Inheritance and Deborah Stein in Hugo Wolf's Lieder and Extensions of Tonality. Numerous articles have appeared in books and journals focusing on a wide variety of subjects.

Studies of Wolf's Goethe-Lieder are less thorough than those of Wolf's other song collections. Most research on the Goethe-Lieder focuses on Wolf's settings of the poems from Wilhem Meister, while only brief summaries of the West-östlicher Divan settings appear throughout the studies of Wolf's songs. The principle exception is author Harry Seelig, who has written extensive analysis of some of the Divan settings, though his primary focus is on the settings from the "Buch Suleika." Only his articles "Hugo Wolf's Seventeen Divan-Settings. An Undiscovered Goethe-Cycle?" and "Hugo Wolf's Ghazel Settings from 'Das Schenkenbuch' of Goethe's West-östlicher Divan" include discussion of any of the five songs of "Das Schenkenbuch."

There is a need for further exploration and discussion of these five songs and how as a group they bring out the exploration of spiritual intoxication in these poems. The idea that Wolf created groups of interrelated Lieder within his larger collections is not 
new: Susan Youens points out groupings in the Mörike-Lieder and Harry Seelig presents a theory of interconnectivity in all of the seventeen West-östlicher Divan settings. In his article, however, Seelig generalizes the role of the five songs from "Das Schenkenbuch" within the Divan settings and does not explore the interconnectivity among the five songs as an independent group.

This thesis will investigate the interconnectivity in the songs and the relationship of the musical settings to the original poetry individually and as a group. I will not address here whether they should be regarded as a mini song cycle inserted into the larger context of the Goethe-Lieder. The claim that these five songs, or even the entirety of the Divan settings, are a song cycle is too multifaceted to approach in the limitations of this thesis. What can be explored is whether or not the five Lieder from "Das Schenkenbuch" of the West-östlicher Divan possess a shared identity in terms of formal, harmonic and motivic structure that illustrate the exploration of wine and spiritual intoxication. 


\section{HUGO WOLF AND THE GOETHE-LIEDER}

\section{Biography of Hugo Wolf}

Born in Windischgraz, Styria (now Slovenj Gradec, Slovenia) on March 13, 1860, Hugo Wolf was the second and favored son of leather manufacturer Philipp Wolf. Wolf had problems with formal education due to his temperamental personality and tendency to ignore other subjects in favor of music. He passed through a number of schools, even leaving the Vienna Conservatory in 1877 after less than two years of study. He continued his education as an autodidact, and his musical knowledge stemmed from the independent study of composers, most prominently Beethoven, Schumann, Schubert, Liszt and Wagner.

Wolf possessed a strong love for and attachment to poetry. ${ }^{5}$ Hermann Bahr recalled Wolf's response to poetry during the summer they spent together in 1883: "He doted on it. His hands trembled when he read only a few lines from it, his eyes shone and, as if in sight of a higher and brighter realm, whose doors had suddenly sprung open before him, he appeared as if transfigured."

Wolf's appreciation for all aspects of poetic expression was vital to his success as a song composer. As Frank Walker stated:

\footnotetext{
${ }^{5}$ Wolf also wrote some poetry, though according to Frank Walker, Wolf was aware of its mediocrity: "Wolf had no poetic pretensions; his taste in literature was sufficiently acute for him to recognize his own limitations in this sphere. But as a young man he did produce a considerable amount of occasional poetry, most of it humorous or satirical in intention, in which the very badness of the verses was part of the joke." Frank Walker, Hugo Wolf: A Biography (New York: Knopf, 1952), 119.

${ }^{6}$ Hermann Bahr, Buch der Jugend (Vienna: H. Heller, 1908), 55.Translated in Frank Walker, 143.
} 
Wolf's astounding ability to bring a poem or a dramatic scene to life, to master the words and meaning until they seemed almost to belong to him alone, to be the creations of his own brain, was to be a decisive factor, fully equal in importance to his purely musical gifts, in the make-up of the greatest song-writer of modern times. It was owing to this that he was able, in his most inspired moments, to fuse fine poetry and his own music into one whole, the incomparably beautiful and enduring alloy that is Wolfian song. ${ }^{7}$

Wolf composed songs in his youth, but did not begin to write the large output of mature songs for which he is famous until $1887 .^{8}$ Before this time he struggled with the difficulties typical for a young, unknown composer seeking recognition for his work. The success in finally locating a firm to publish some of his Lieder at the end of 1887 marked a change in Wolf's luck and brought a more focused approach to composition.

Knowing that he needed quiet in order to compose, he intentionally secluded himself beginning in January of 1888 at the summer home of a friend in Perchtoldsdorf. In this seclusion his most fruitful years of composition began with the composition of the Mörike-Lieder. Though he left Perchtoldsdorf after the winter, Wolf's continued attentiveness and dedication to his needs for successful composition - as well as the constant support of his friends - enabled the completion of four volumes of Lieder from the poetry of Mörike, Eichendorff, Goethe, and Heyse and Geibel's translation of the Spanisches Liederbuch by the conclusion of April 1890 - 161 Lieder composed in the course of twenty-six months.

Hugo Wolf's fame as a song composer rests on these four songbooks as well as on the Italienisches Liederbuch and the later, smaller collections composed before his death in 1903. Schumann and Wagner were influences in the compositional style of these

\footnotetext{
${ }^{7}$ Frank Walker, 165.

${ }^{8}$ Wolf composed in other musical genres, most notably the symphonic poem Penthesilea (1883-83) and the opera Der Corregidor (1895), but they do not match the artistic success of his Lieder.
} 
volumes. The voice and piano support the meaning of the poem as equal partners, though Wolf occasionally used contrasting interpretations in them to allow a better depiction of the subtlety of the poetry. A dramatic declamation of the vocal line, inspired by Wagner's treatment of text, allows a more intuitive reading of the poem that is not restricted by the needs of lyricism. Additionally, Wolf drew from the increasingly chromatic language of Wagner and other Romantic composers to add harmonic complexity to his musical settings.

The poetry always came first. Pictures of the poet appeared on the cover of Wolf's published works, and he insisted that the name of the poet appear above his own on the title page. Wolf's composition on the works of only one poet at a time focused his writing and created an individual reaction to each poet. This focus gives each of Wolf's major collections a unique aesthetic identity. Frank Walker summarized the first three major Lieder collections:

We may say that the Mörike songs were written because Wolf could not help himself - because he was possessed by the poet. The Eichendorff songs give the impression of having been more of a relaxation. The Goethe volume, on the other hand, seems almost the product of a conscious stiffening of the musician's will and girding of his loins to meet the challenge of the greatest of German poets. To match the splendor of this poetry, in which the heart and intellect are so uniquely blended, its depth and range of thought, its wisdom, and its beauty - here was a test that no singer who aspired to the highest could decline.

\section{Biography of Johann Wolfgang von Goethe}

The works of Johann Wolfgang von Goethe (1749-1832) contributed to both the Sturm und Drang and Romantic movements in German literature. He was not only a poet

\footnotetext{
${ }^{9}$ Frank Walker, 239-40.
} 
and writer, but was also a political advisor, scientist and humanist. His vital role in German culture was summarized by John Williams:

He lived through, and also contributed crucially to, the emergence of the German language and German literature from a position of neglect and even contempt, when the King of Prussia himself could dismiss his own tongue as uncouth and barbarous, to a status of parity among European cultures as the language of 'a people of poets and thinkers.' 10

Goethe was born in 1749 in Frankfurt am Main, the first child of a prosperous family. Following his father's wishes, Goethe studied law at Leipzig University and Strasbourg. The arts, however, especially literature, drew his interest and by 1774 he had completed his first literary achievement: Die Leiden des jungen Werthers (The Sufferings of Young Werther). Shortly thereafter he met Duke Karl August of Sachsen-Weimar, whose court he joined in 1775 .

Goethe remained under the Duke's patronage for the rest of his long life, and his connection to the court involved him in the attempt to end the French Revolution by the Austro-Prussian coalition and the conquests of Napoleon. He was a vital part of the cultural prominence of Weimar that was cultivated by Karl August's mother, the Dowager Duchess Anna Amalia. This cultural prominence culminated in the decade of Weimar Classicism from 1794 to 1805.

Goethe is well-known for his novels and plays, including Wilhelm Meisters Lehrjahre, Wilhelm Meisters Wanderjahre, Faust and Egmont. These works and others inspired numerous musical compositions, and Goethe's works appear frequently as the texts of Lieder. ${ }^{11}$ While many songs are drawn from Goethe's novels and plays (most

\footnotetext{
${ }^{10}$ John R. Williams, The Life of Goethe: A Critical Biography (Oxford: Blackwell Publishers, 1998), 3.

${ }^{11}$ Goethe preferred musicians to set his poems in strophic form. Amanda Glauert noted that Goethe "seems to have doubted whether composers could exert a similarly conscious control upon their material, or create
} 
famously Schubert's "Gretchen am Spinnrade" from Faust and the Mignon and Harper songs from Wilhelm Meisters Lehrjahre), others are drawn from his independent lyric poems.

The vast range of Goethe's lyric poetry resists all but a few general descriptions as the poems vary in topic and style according to the periods of Goethe's life. The close connection between Goethe's poetry and the events of his life partially creates the variety of styles. However, a few general characteristics of Goethe's poetic style do apply throughout the poet's long life. Multiple meanings of words and phrases make Goethe's poems difficult to translate into other languages. Satire and double-meanings appear often in his poetry. Additionally, there is careful attention to form and syllabic stress, even though the formal constructions change between poems and periods. Finally, there is a command of the diction, sounds, and construction of the German language. These characteristics made Goethe the most revered poet of his generation, perhaps of all German literary history, and his poetry naturally was a ripe source of musical inspiration. Settings of his poems are frequent in German art songs, and Wolf had already set a few of Goethe's poems to music before the feverish compositional months when he composed the fifty-one songs that comprise the Goethe-Lieder.

\section{The Goethe-Lieder}

Wolf focused on the works of Goethe from October 1888 to February 1889 and emerged from the challenge with a volume of 51 Lieder spanning a large breadth of Goethe's poetic works. ${ }^{12}$ Eric Sams commented:

\footnotetext{
an equivalent balance between form and expressive content. Amanda Glauert, Hugo Wolf and the Wagnerian Inheritance (Cambridge: Cambridge University Press, 1999), 80.

${ }^{12}$ Wolf wrote fifty of the Goethe-Lieder in the October-February span. The final Lied, Die Spröde, was not composed until October 1889.
} 
No single Goethe selection could possibly be wholly representative of the c. 700 poems in his published Gedichte; but Wolf contrives to draw at least one sample from every suitable section except the sonnets. In this sense the songbook is as commensurate with the breadth of Goethe's outlook as with the depth of his thought and feeling. ${ }^{13}$

The collection opens with ten songs from Goethe's novel Wilhelm Meisters Lehrjahre, and the twenty-one songs that follow are taken from a variety of sources, including plays, independent lyric poetry, and Singspiel. The next seventeen songs are from the West-östlicher Divan, a later work by Goethe that integrates elements of Germany and Persia. Finally, "Prometheus," "Ganymed" and "Grenzen der Menschheit," close the collection. Throughout the collection, Wolf ordered the Lieder according to characteristics such as source, type of song and subject. Although Wolf did this with his other Lieder collections, it is especially fitting with Goethe, who ordered his own published poems organized according to a general flow of different characteristics.

In addition to the intellectual and artistic challenge Wolf faced in Goethe's poetry, he also had to consider the large number of Lieder that already existed on the poetry of Goethe. It was Wolf's practice to not challenge a satisfactory musical setting of a poem by another composer. Though Wolf's standards for an acceptable Lied were high, he encountered Schubert's, Schumann's and other composers' legacies to a greater extent with Goethe than with any other of his chosen poets. Such encounters include the Wilhelm Meister settings that open the collection as well as with the lyric trilogy that concludes it.

\footnotetext{
${ }^{13}$ Eric Sams, The Songs of Hugo Wolf (Bloomington, IN: Indiana University Press, 1992), 180.
} 
Avoiding pre-existing settings in the central Lieder of the collection resulted in several songs that have earned a bad reputation among critics. ${ }^{14}$ However, Ernest Walker acknowledged that "all said and done, Wolf, of all song writers, comes nearest to Goethe in that, for better or worse, he adventured everything." 15 The Goethe-Lieder collection represents a large cross-section of different types of poems and subjects, and Wolf naturally changes his approach with each poem, whether or not the outcome is among the best of his work. The style of the Goethe-Lieder as a collection is therefore diverse yet unified by Wolf's aesthetic approach to Goethe.

This approach includes many aspects of Wolf's standard compositional style: avoidance of text repetition, regularity of phrase length, the use of motives with associated meanings and the independent roles of voice and piano. The vocal lines in the Goethe-Lieder tend to be more speech-like and often have a free Wagnerian declamation as opposed to the more lyrical moments in the Mörike and Eichendorff collections. ${ }^{16}$ The freedom of the vocal line is enabled by the use of piano to establish the meter and phrasing. The piano also provides an opportunity for Wolf to allow the different interpretations of the text, as Goethe often uses double meanings.

\footnotetext{
${ }^{14}$ In his biography of Wolf, Frank Walker stated that "It must be admitted that there are uninviting stretches among the miscellaneous songs in Wolf's Goethe volume. The composer seems to have had to search far afield to find unhackneyed poems for musical treatment, and among the garland with which he returned are some rather prickly, thistle-like growths." Frank Walker, 241.

${ }^{15}$ Ernest Walker, "Goethe and Some Composers" in The Musical Times 73, no. 1072 (June 1932): 500.

${ }^{16}$ Frank Walker noted that "there is here no profuse lyrical outpouring as in the Mörike song-book. The response is intellectual rather than lyrical." Frank Walker, 240.
} 
THE WEST-ÖSTLICHER DIVAN

\section{The Genesis of the West-östlicher Divan}

Despite his close association with the government of the Duchy of Weimar, as

Goethe grew older he adopted what John Williams described as "a notoriously ambivalent stance. ${ }^{17}$

His tendency to affirm the status quo, his abhorrence and fear of violent or even radical change, were profoundly rooted in his nature, intellectually and temperamentally....More strictly, his instincts were apolitical... [that] corresponded to a fundamental need...to rise above factionalism and to maintain an ironic mediation between warring parties. ${ }^{18}$

Amidst the political upheaval caused by Napoleon's defeat and the Congress of

Vienna, Goethe immersed himself in the work of the fourteenth-century Persian Sufi poet Shams-ud-din Muhammad, known by the pen name of Hafiz. Though there is not much reliable information on Hafiz's life, including exactly how many poems he wrote (estimated to be anywhere between 800 to several thousand), it is generally accepted that he was born in Shiraz and rose from a low-income background to the service of the Muzaffarid dynasty that ruled over Shiraz during his lifetime. As one of the most-revered poets of Persian history, he left

a body of poetic utterance that is regarded by Persian-speakers as sublime to the point of near-sacredness. Hafiz' Divan is read or memorized, and quoted, at all levels of society, but it is also used - by those who call it a "Qur'an in Persian" - in all solemnity to take random auguries at such

\footnotetext{
${ }^{17}$ John R. Williams, The Life of Goethe: A Critical Biography (Oxford: Blackwell Publishers, 1998), 42.

${ }^{18}$ Ibid., 43.
} 
important moments in life as a projected marriage, a business or medical decision, the start of a lengthy journey, and so on. ${ }^{19}$

Hafiz's poems are often ambiguous and filled with symbolism, and, as noted by G. M. Wickens, Hafiz "generally carried, and made frequent reference to, a reputation for aggressive nonconformity. ${ }^{, 20}$ Spirituality plays an important role in Hafiz's poetry, especially the search for and love of the Beloved, representing God. Hafiz is best-known for his use of the ghazal form of poetry - a meditative-like repetition of rhyme throughout several lines of poetic text, usually twelve to fifteen.

Whether Goethe was inspired by Hafiz's large corpus of work to continue writing in his old age, or whether his encounter with Persian culture was intellectual escapism from the tumult of European politics, the creation of the West-östlicher Divan represented a meeting-ground between these two great poets of the Eastern and Western tradition. Though Goethe's inspiration and primary reference was the poetry of Hafiz, Goethe also consulted with leading Arabic experts so that he could correctly portray the Persian world of Hafiz. ${ }^{21}$ This ultimately led to the writing of the Noten und Abhandlungen zu besserem Verständnis des West-östlichen Divans, where Goethe poured out all of his knowledge so that readers could better understand what he had sought to achieve within the Divan.

Goethe's intellectual retreat to the world of Hafiz and the inspiration for the Westöstlicher Divan were accompanied by a rejuvenating trip to the Rhineland. Goethe's burst of creative energy was further stimulated by his meeting with Marianne von Willemer, the wife of a Frankfurt banker. The two instantly formed a close relationship. Marianne

\footnotetext{
${ }^{19}$ G.M. Wickens, "Hafiz Shirazi" in The Encyclopedia of Religion, ed. Mircea Eliade (New York: Macmillan Publishing Company, 1987), 6: 152.

${ }^{20}$ Wickens, 152.

${ }^{21}$ Goethe was also able to draw from previous research on the Orient which he had pursued since his student days at Strasbourg.
} 
inspired and influenced his work heavily, and some of her poems were even included in the Divan. The lovers Hatem and Suleika within the Divan's pages were the fictional counterparts of Goethe and Marianne, illustrated in the often-quoted passage from

"Locken, haltet mich gefangen":

Du beschämst wie Morgenröte jener Gipfel ernste Wand, und noch einmal fühlet Hatem

Frühlings hauch und Sommerbrand.

In this example the name "Hatem" breaks the rhyme pattern in a case where the poet's actual name, "Goethe" would complete it correctly, indicating a connection between Goethe and his character. Though Marianne had an undeniable effect on the work of the Divan, her direct influence was limited to the collection's early stages: the pair did not see each other after 1815, while Goethe's study of the east and writing for the Divan continued for years.

\section{$\underline{\text { Structure and Style of the Divan }}$}

Organization within the Divan is based on a division by subject into thirteen books: "Buch des Sängers," "Buch Hafis," "Buch der Liebe," "Buch der Betrachtungen," "Buch des Unmuts," "Buch der Sprüche," "Buch des Timur," "Buch Suleika," "Das Schenkenbuch," "Buch der Parabeln," "Buch des Parsen," "Buch des Paradieses" and "Aus dem Nachlaß." The organization of both the overall collection and the different books is the subject of much debate. Specific characters (Hafiz, Hatem and Suleika) and broad situations (Hatem and Suleika's relationship, the reception of Hafiz's poetry) echo throughout the entire volume, but these are not organized in any specific construction. Within each book the poems are loosely tied together by subject, although there can be 
moments of continuity. There is a large variety of poem lengths, subjects, and forms, and the only true common thread is the encounter between Eastern and Western cultures and a discussion of how they can be synthesized together in poetry.

Goethe references the poetry of Hafiz in a number of ways. The most apparent are direct allusions to Persian elements such as turbans, Mohammad, the Koran, and the Tigris and Euphrates. Goethe also utilizes themes and symbols prevalent in Hafiz's poetry: the nightingale, intoxication and divine love. The only Persian poetic form that Goethe adopts outright is the ghazal, and the majority of the poems are written in western poetic forms, most commonly trochaic tetrameter.

More important than the use of Persian references is the way in which Goethe combines the identities of east and west:

The figure of Timur (Tamberlaine) merges with that of Napoleon; the political unrest of the age of Hafiz is assimilated to the contemporary endgame of the continental wars and the Congress of Vienna; the lovers Hatem and Suleika play out the private emotional dialogues of Goethe and Marianne von Willemer...the poppies in the fields near Erfurt bloom like the roses of Shiraz. 22

The thematic joining of east and west is also evident in "Das Schenkenbuch," as Goethe merges Sufi concepts of wine and intoxication with contemporary and traditional German perspectives.

\section{Converging meanings in "Das Schenkenbuch"}

Like many books in the Divan, "Das Schenkenbuch" consists of an eclectic collection of poems held together by a loose theme, in this case a discussion of the role of wine. Some poems are attributed to a specific narrator (the lovers Hatem and Suleika, the

\footnotetext{
22 John R. Williams, "Goethe the Poet," in The Cambridge Companion to Goethe, edited by Leslie Sharpe (Cambridge: Cambridge University Press, 2002), 53-4.
} 
Poet, and the cupbearer Saki) while some have no designation. There are dialogues between characters as well as independent lyrics that include various forms and meters including the Persian ghazal, the trochaic tetrameter Goethe used often in the Divan, short epigrams and dialogue. The poems flow freely from one to another, and Goethe's only major formal delineation is the demarcation of the final four poems under the heading "Sommernacht." 23

The multiple levels of meaning within "Das Schenkenbuch" derive from Goethe's own penchant for double meanings, the interaction of the Persian and Germanic perspectives of alcohol, and most importantly, the intricate symbolism utilized by Hafiz and other Sufi poets. Sufism is a mystical movement within Islam, and during the time of Hafiz's life, Sufis were periodically persecuted by the ruling families. Sufi teachings were disseminated through poetry frequently set to music, for, as Henry Mindlin remarked, "Poetry and song, easy to memorize and repeat, were used as teaching materials to encapsulate or summarize spiritual principles. ${ }^{24}$ Within this tradition of poetry, a rich network of symbolism developed that reached its height in the works of Hafiz.

Some of the favorite symbols used by Sufi poets were those of wine, the tavern and intoxication. This stems from the importance of metaphorical intoxication and sobriety in Sufi tradition. Sobriety reflected "one's 'natural' spiritual condition, prior to ecstatic experience. ${ }^{25}$ The state of ecstasy, where one could unite more fully with God, was likewise considered intoxication. This basic dichotomy of sobriety and intoxication

\footnotetext{
${ }^{23}$ The "Sommernacht" poems all involve the characters of the cupbearer and the poet.

${ }^{24}$ Henry S. Mindlin, "Introduction: The Life and Work of Hafiz" in The Gift: Poems by Hafiz, the Great Sufi Master, trans. by Daniel Landinsky (New York: Penguin/Arkana, 1999,17.

${ }^{25}$ John Renard, Historical Dictionary of Sufism (Lanham, MD: The Scarecrow Press, Inc., 2005), 225.
} 
created many other symbols, notably wine, usually representing the beauty of the Beloved, as the inducer of religious ecstasy. ${ }^{26}$

This symbolism is prominent as Goethe sets the context of "Das Schenkenbuch" within the Persian tradition with references to the Koran and the presence of Saki, the traditional Sufi character of the Cupbearer who "bring[s] on the wine of love that in turn yields to the salutary bewilderment the mystic experiences in the presence of the Beloved. ${ }^{, 27}$ Love is a key element in spiritual intoxication and was one of the foundations of Hafiz's poetry. In fact, the common legend of Hafiz's start of religious study includes the motivation of love, first for a beautiful young woman and then for God. ${ }^{28}$

Goethe's poems in "Das Schenkenbuch" also include the critical view of the "intoxication" of Sufi spiritual enlightenment held by the opponents of Sufism. In the states of religious ecstasy, Sufi mystics often made claims of union with God that were considered heretical by the religious government. In one such instance, a Sufi named alHallaj was executed in 922 for stating "I am God." 29 The condemnation of wine in the Koran is often used in "Das Schenkenbuch" to refer to the criticism of such "intoxicated" statements of faith.

The perception of drinking in the German tradition contains both similarities to and differences from the Persian tradition that are evoked by Goethe. Both traditions recognize the connection between love and alcohol as well as the use of intoxication to

\footnotetext{
${ }^{26}$ Renard, 123.

${ }^{27}$ Ibid., 67.

${ }^{28}$ Mindlin, 11-12.

${ }^{29}$ Fazlur Rahman, "Islam: An Overview" in The Encylopedia of Religion, Mircea Eliade, ed. (New York: Macmillan Publishing Company, 1987), 7: 314.
} 
represent something more significant than banal drunkenness. ${ }^{30}$ However, the image of German fondness for alcohol, dating back to the time of the Roman Empire, is the opposite of the condemnation of alcohol in the Islamic religion. ${ }^{31}$ The traditional perception of alcohol in Germany includes references to wine (interchangeable with beer or other alcoholic spirits) as a way to dismiss worries or to seize the moment before age or death can take it away. ${ }^{32}$

However, in 1815 attitudes toward alcohol were changing. The Enlightenment and the rise of the middle class in the eighteenth and nineteenth centuries began a movement towards self-control and the vilification of alcohol. As stated by James Roberts,

In Early Modern Europe... alcohol had been accepted as one of God's gifts. Man was believed to possess the moral freedom to either use it rationally or to abuse it. What replaced this earlier view was an almost Manichean vision which ascribed independent, demonic powers to alcohol. Alcohol was removed from the arena of man's moral discretion; instead of serving man, alcohol now threatened to...control human behavior, destroy the rational will, and thus lead man, his moral defenses shattered and his bestial instincts given free rein, to self-destruction and social evil. ${ }^{33}$

\footnotetext{
${ }^{30}$ Amanda Glauert specifically mentions divine creativity. Amanda Glauert, Wolf and the Wagnerian Inheritance (Cambridge: Cambridge University Press, 1999),81.

${ }^{31}$ B. Ann Tlusty notes that "Tacitus advanced the opinion in the second century A.D. that inviting German men to drink to their hearts' content would do more to bring them down than could be accomplished in battle." Tlusty, Bacchus and Civic Order: The Culture of Early Drink in Early Modern Germany (Charlottesville, VA: University Press of Virginia, 2001), 3.

${ }^{32}$ Hans Ritte, Das Trinklied in Deutschland und Schweden: Vergleichende Typologie der Motive. Bis 1800 (Munich: Wilhelm Fink Verlag, 1973), 99-100, 225-26.

${ }_{33}$ James S. Roberts, Drink, Temperance and the Working Class in Nineteenth-Century Germany (Boston: Allen \& Unwin, 1984), 6.
} 


\section{THE FIVE SONGS}

Wolf"s composition of the five "Schenkenbuch" Lieder took place in the span of three days, January $16-18,1889 .{ }^{34}$ Though the poems were published in the order that they appear in Goethe's Divan, they were composed in a different sequence. ${ }^{35}$ The central and last songs in the collection were written first, on January 16. "Ob der Koran," the opening Lied, followed on January 17. Wolf completed the second and fourth Lieder in the sequence on January 18 .

The poems that Wolf selected are all independent lyrics and are not part of the direct dialogues between characters, though they follow one another in the text. The first three songs come from consecutive texts starting with the fourth poem of "Das Schenkenbuch," "Ob der Koran von Ewigkeit sei?" Dialogues separate these poems from the texts of the final two songs, which are separated from each other in "Das Schenkenbuch" by one poem ("Du kleiner Schlem du!").

\section{I. "Ob der Koran von Ewigkeit sei?"}

Ob der Koran von Ewigkeit sei?

Darnach frag' ich nicht!

Ob der Koran geschaffen sei?

Das wei $\beta$ ich nicht!

$\mathrm{Da} \beta$ er das Buch der Bücher sei, Glaub' ich aus Mosleminenpflicht.
Whether the Koran existed from eternity?

About that I question not!

Whether the Koran was created?

That I know not!

That it is the Book of Books, I believe out of Muslim duty,

\footnotetext{
${ }^{34}$ Before the Schenkenbuch Lieder, Wolf had not completed a Lied since January $11^{\text {th }}$, when he composed "Ganymed." After the conclusion of the "Schenkenbuch" Lieder, Wolf composed the rest of the Divan settings, beginning with "Phänomen" on January $19^{\text {th }}$.

${ }^{35}$ Eric Sams and Susan Youens, "Hugo Wolf" in The New Grove Dictionary of Music and Musicians, $2^{\text {nd }}$ ed., ed. by Stanley Sadie and John Tyrrell (New York: Grove Dictionaries, 2001), 27: 494.
} 
$\mathrm{Da} \beta$ aber der Wein von Ewigkeit sei, Daran zweifl' ich nicht.

Oder daß er von den Engeln geschaffen sei, Ist vielleicht auch kein Gedicht. Der Trinkende, wie es auch immer sei, Blickt Gott frischer ins Angesicht.
But that wine has existed from eternity, On that I do not doubt.

Or that it was created by the angels, Is perhaps also not a tale.

The drinker, as it also always is, Looks more freshly at the face of God. ${ }^{36}$

"Ob der Koran von Ewigkeit sei?" is one of two ghazal forms in the

"Schenkenbuch" Lieder. Following the Persian poetic form, twelve lines of alternating "sei" and "-icht" rhymes create a repetitive pattern underneath a developing discussion of the speaker's Muslim faith. The speaker is confronted by a religious conflict between Turkish and Persian sects of Islam: whether the Koran existed from eternity or whether it was created by God. ${ }^{37} \mathrm{He}$ avoids committing to either side of the debate, citing that his faith in the Koran as the book of books should be adequate. However, the speaker's confidence in the importance of wine is a contrast to his obligatory faith in the Koran. Ultimately, wine is portrayed as a component of faith that moves past the intellectual nature of debates and facilitates a truer look at God.

The poem divides into two six-line sections that represent intellectual discussion in the form of the debate over the Koran's origin and the enlightenment of wine. Both the Koran and wine are introduced in the same context: the question of their origin. However, both the text and Wolf's musical setting illustrate how the religious experiences of intellectual debates and intoxicated revelation differ.

The questions regarding the Koran's origin, shown in Example 1, are among the most noted aspects of the song. A forte line ascending from A-E in parallel octaves

\footnotetext{
${ }^{36}$ German translations are the author's.

${ }^{37}$ J.W. Goethe, West-östlicher Divan, ed. Max Rychner (Zurich: Manesse, 1963), 533, cited in Seelig, 380.
} 
illustrates the gravity of the questions, so important that they echo after the question has been $^{\text {asked. }}{ }^{38}$

Example 1 "Ob der Koran von Ewigkeit sei?" mm. 1-5

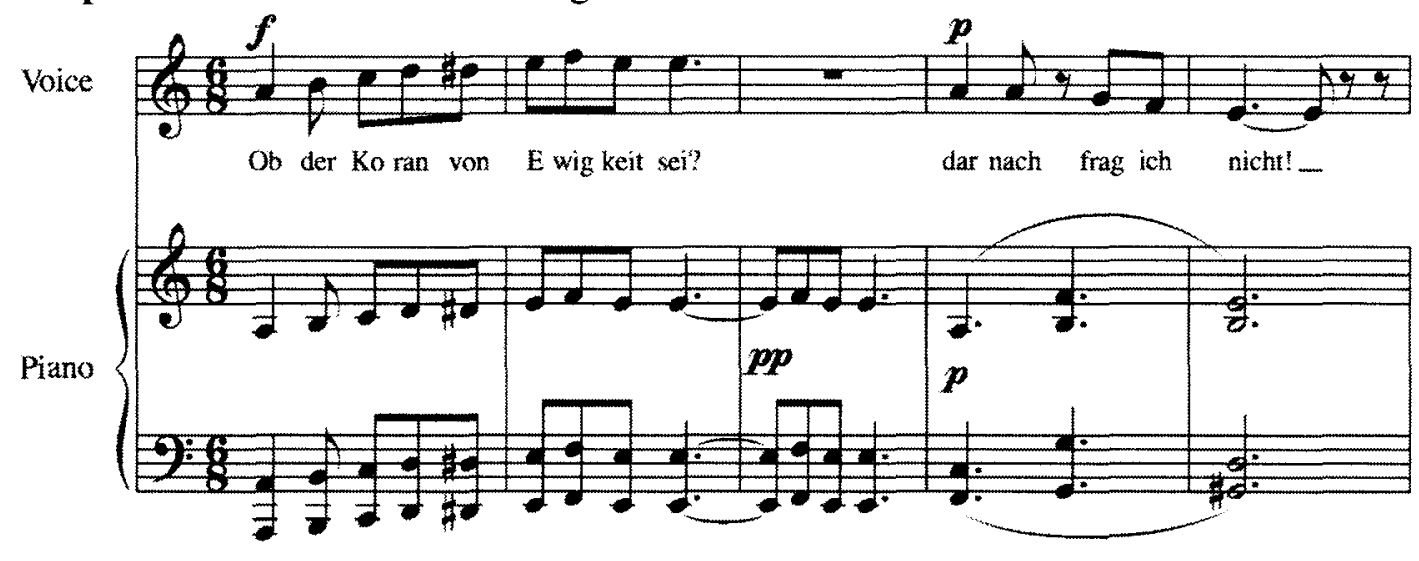

The speaker's reply, on the other hand, is set as a quietly descending vocal line with simple chordal accompaniment. The change in dynamic, the introduction of chords and the change in melodic direction from ascending to descending dramatically contrast the speaker's evasive replies against the questions of the Koran's origins. Both the initial question and the speaker's reply end on a half cadence; no conclusion has been reached. The second question of the Koran's origin that follows uses the same contrast between the question and the speaker, but the ascending scale rises even further to a sixth. The speaker's reply retreats emphatically from answering the question, which Wolf portrays by adding leaps to the descending structure of the first reply and moving harmonically towards the relative major (though it is cast as a dominant-seventh chord).

The next couplet of text turns from the questions of the Koran's origins to what the speaker already believes: the holiness of the Koran. The vocal line contains a scalar ascent to show the relationship of the text to the opening questions, but the chordal

\footnotetext{
${ }^{38}$ Eric Sams identifies the octave unison between voice and piano as a recurring motive in Wolf's songs that represent "simplicity" and "directness." Eric Sams, The Songs of Hugo Wolf (Bloomington, IN: Indiana University Press, 1992), 32.
} 
accompaniment in the piano maintains the musical connection to the speaker's perspective. The brief, if unstable, cadence in $\mathrm{G}$ minor signifies that the speaker believes that that is all the discussion necessary: he believes, as a faithful Muslim, that the Koran is the book of books and there is no need for debate over the particulars of the Koran's origins. As the poem shifts to the subject of wine, shown in Example 2, musical contrasts are added to transition away from the discussion of the Koran.

Example 2 "Ob der Koran von Ewigkeit sei?" mm. 14-18

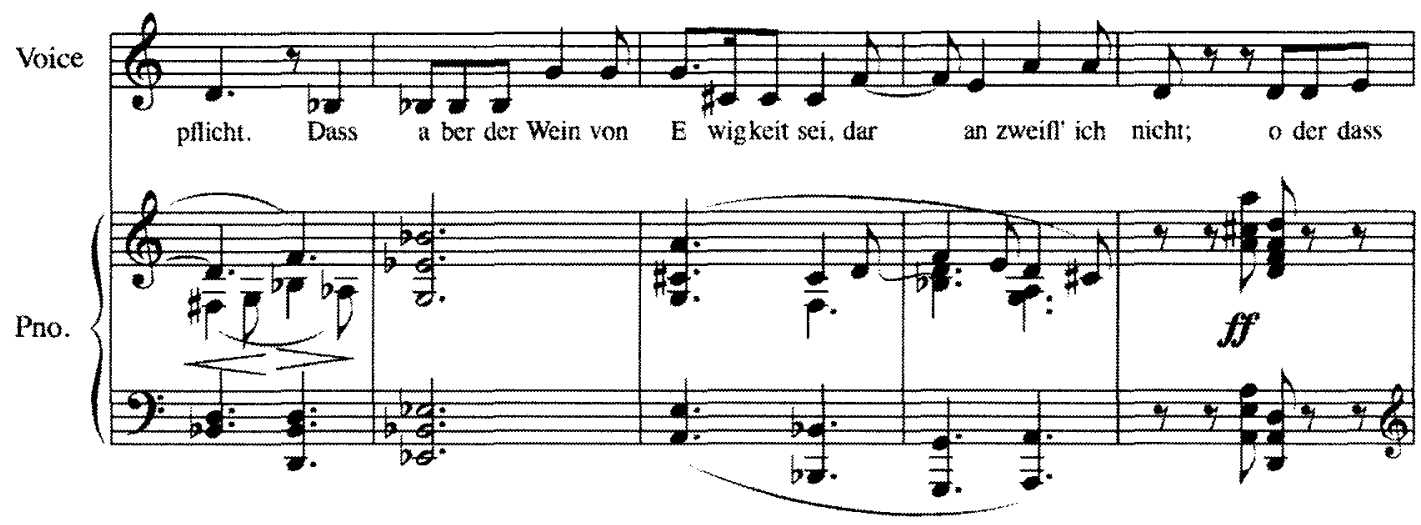

A sudden arrival in $E^{\mathrm{b}}$ major and a change to repeated notes and leaps in the vocal line highlight the shift of subject from the Koran to wine. ${ }^{39}$ However, a chordal accompaniment continues in the piano and maintains a link to the speaker's perspectives in the debate over the Koran's origin. This perspective is not unchanged by the shift of the text to wine; increased melodic movement appears in the right hand of the piano and reflects an aspect of the speaker unseen in the discussion about the Koran.

\footnotetext{
${ }^{39}$ The intervals of these skips maintain a connection to the scalar ascents of the previous phrases by retracing the overall intervals of each scalar ascent: major sixth (ascending $B^{b}-G$ in measure 15 corresponding to $\mathrm{C}-\mathrm{A}$ in measure 11 and $\mathrm{A}-\mathrm{F} \#$ in $\mathrm{mm} .6-7$ ) and a perfect fifth(descending $\mathrm{A}-\mathrm{D}$ in measure 18 , corresponding to A-E in mm. 1-2).
} 
Seelig characterizes the entrance of the $E^{b}$ major in measure 15 as "dramatiz[ing] the utter polarity of Koran and wine with monumental clarity. ${ }^{" 40}$ Though Seelig does not address it directly, part of the "polarity" emerges from the tritone interval between $E^{b}$ major and the tonic A minor. This polarity marks the midway point in the poem, and Wolf develops this first statement regarding wine into an emphatic cadence in D minor in measure 18 to mark the discussion of wine as the beginning of a new musical section.

The introduction of a clear metric pulse in measure 19 is the largest indicator of the musical distinction between the nature of wine and the nature of intellectual debate, though other contrasts appear in both the piano and voice. While the text of the penultimate couplet ("oder da $\beta$ er vor den Engeln...") in measure 18 contains a scalar ascent reminiscent of the song's opening, the bass drops out of the piano accompaniment. The intimidating octave questions of the Koran's origins are replaced with a sound akin to the tinkling of angelic bells.

These musical effects support the idea that an understanding of wine's origins is not vital to the enjoyment of it. In fact, the speaker can entertain the notion that wine has both existed from eternity and was "perhaps" also created by the angels. Without intellectual debate, wine allows a better look at the true nature of God, communicated in the final couplet of text. This final vocal proclamation begins with a single-note declamation not heard before in the song, provides the first authentic cadence in the original tonic, and recasts the tonic A minor as A major. These musical elements reinforce that the experience of God is a state that the intellectual debates of the opening of the song cannot reach.

\footnotetext{
${ }^{40}$ Harry Seelig, "Hugo Wolf's Ghazel Settings from Goethe's 'Schenkenbuch,"' in The Romantic Tradition: German Literature and Music in the Nineteenth Century, ed. by Gerald Chapple, Frederick Hall and Hans Schulte (Lanham, MD: University Press of America, 1992) 386.
} 
The piano postlude continues the A major associated with the achievement of spiritual satisfaction and adds syncopation to further reflect the joy of the speaker. ${ }^{41}$ However, the cadential movement of the postlude is primarily plagal. This provides a final support that wine, the discussion of which was accompanied by $\mathrm{D}$, is the instigator of this spiritual experience, not the traditional authentic cadence that had been attempted unsuccessfully in the half cadences of the opening debate.

\section{II. "Trunken müssen wir alle sein!"}

Trunken müssen wir alle sein! Jugend ist Trunkenheit ohne Wein; Trinkt sich das Alter wieder zu Jugend, So ist es wundervolle Tugend. Für Sorgen sorgt das liebe Leben, Und Sorgenbrecher sind die Reben.

Da wird nicht mehr nachgefragt! Wein ist ernstlich untersagt. Soll den doch getrunken sein, Trinke nur vom besten Wein: Doppelt wärest du ein Ketzer In Verdammnis um den Krätzer.
We should all be drunk!

Youth is drunkenness without wine; The old drink themselves back to youth, Such is a wonderful virtue. Dear life sees to providing worries, And the breakers of concerns are the vines.

This will no longer be discussed! Wine is strictly forbidden. Should you then anyway be drunk, Drink only the best wine: Doubly would you be a heretic To be damned over dregs.

The most intriguing aspect of this Lied is that Wolf creates it out of two separate poems from "Das Schenkenbuch:" "Trunken müssen wir alle sein!" and "Da wird nicht mehr nachgefragt!" Wolf's combination of the two poems is not without poetic justification. The poems appear consecutively in "Das Schenkenbuch" and, despite the diversity of structures in the Divan, they share several formal similarities. Both contain six lines of trochaic tetrameter with an AABBCC rhyme structure. Furthermore, both

\footnotetext{
${ }^{41}$ Eric Sams links this syncopation to another of Wolf's common motivic devices related to "the waking sensation of losing control, or being overcome." While an association with intoxication in this instance would be an exaggeration, Sams also links similar syncopation to "spiritual exaltation" that would be appropriate here. Sams, 34 .
} 
feature feminine endings, alliteration, an exuberant opening line, and reflect development in the text through changes to the poetic meter.

Despite their many similarities, both poems are independent entities with structural and thematic differences. The metrical pattern of "Trunken müssen wir alle sein!" changes throughout the poem from trochees to more relaxed iambs while "Da wird nicht mehr nachgefragt!" maintains a strict trochaic meter throughout. Thematically the poems portray the general topic of drinking from different and opposing perspectives. "Trunken müssen" decrees that all should drink wine to return themselves to carefree youth while "Da wird nicht mehr" makes an allowance for the consumption of good wine despite the condemnation of alcohol for "one would be doubly a heretic to be damned over bad wine."

Wolf acknowledges the different poems used in the Lied musically and delineates the change in text with a change of tempo, key (F\# minor to A major) and time signature (6/8 to $2 / 4)$. He also marks the change in text with a strong cadence at the end of the first poem and includes more than a full measure of silence between the poems. The return of the opening theme at the conclusion creates a sectional form of rounded binary. While Wolf binds the two poems musically in order to form a unified Lied, he also supports each poem's individual character. This permits the consideration of each poem individually and as a combination.

Wolf structures the content of both poems according to their AABBCC rhyme structure, creating three independent parts within each poem with individual vocal and pianistic characteristics. In "Trunken müssen," the vocal line reflects the poem's syllabic shift from the stressed-unstressed trochaic meter of the opening to an unstressed-stressed 
iambic meter beginning with the fourth line. This change, coupled with the addition of unstressed feminine endings to the end of the last four lines, creates a sense of relaxation in the poem and reflects the text's belief that wine can transport the old back to carefree youth.

Wolf highlights the stages of this metric shift throughout the course of the three rhyming couplets of "Trunken müssen." The length of notes in the first section (mm. 112) reflect the trochaic meter of the first couplet; all unstressed syllables last only an eighth note while the stressed syllables are all at least four times that length. Wolf prepares for the transformation that follows by weakening the metric pulse by avoiding the placement of stressed syllables on downbeats. In the second couplet (set in measures 13-20), Goethe transitions from trochaic to iambic meter by opening the fourth line with two stressed syllables to break up the trochaic pattern. Wolf accentuates this transformation by setting this transitional line (mm. 17-20) in a single-note declamation that stresses the metric pulse of each syllable. Against this stress, the matching of the new iambic pulse of the third couplet (mm. 21-31) with a free-flowing and lyrical vocal phrase luxuriates in new-found relaxation. Finally, Wolf increases the sense of repose at the conclusion of the poem by gradually increasing the length of notes in the final line in measures $25-29$, as though the poet is stretching and relaxing in enjoyment of his carefree existence.

The three sections of piano accompaniment in the opening poem of "Trunken müssen" work with these developments in the vocal line to further support the poem. The piano accompaniment of the first phrase is the most prominent and memorable with its pulsing quarter-eighth rhythm and neighbor-tone figure stressing the downbeat, as shown 
in Example 3. With limited melodic movement in the vocal line, this piano line functions as the main theme of the entire Lied.

Example 3 "Trunken müssen wir alle sein!" mm. 1-4

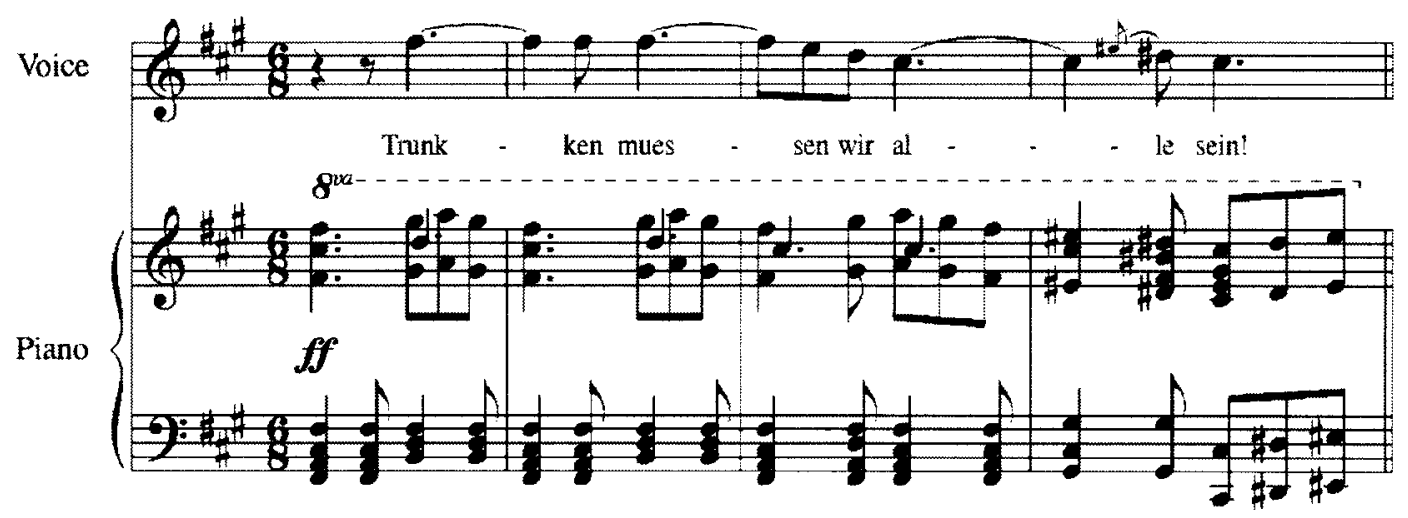

While the piano line of the other two sections of "Trunken müssen" do not have the thematic primacy of the opening section, they still carry individual characteristics that identify the section and support the text. The second section takes the neighbor tone of the opening theme and turns it into an oscillating pattern of chords in the same mechanical rhythm of the vocal line. The third section, shown in Example 4, also contains this motion, but inserts motives in octaves between each measure to break up the chordal texture with a thinner octave texture. This device also reflects the clarity and carefree desires in the text as the opening theme returns in the piano under the word "Reben" ("vine," m. 28) to close the section before the start of the next poem. 
Example 4 "Trunken müssen wir alle sein!" mm. 21-24

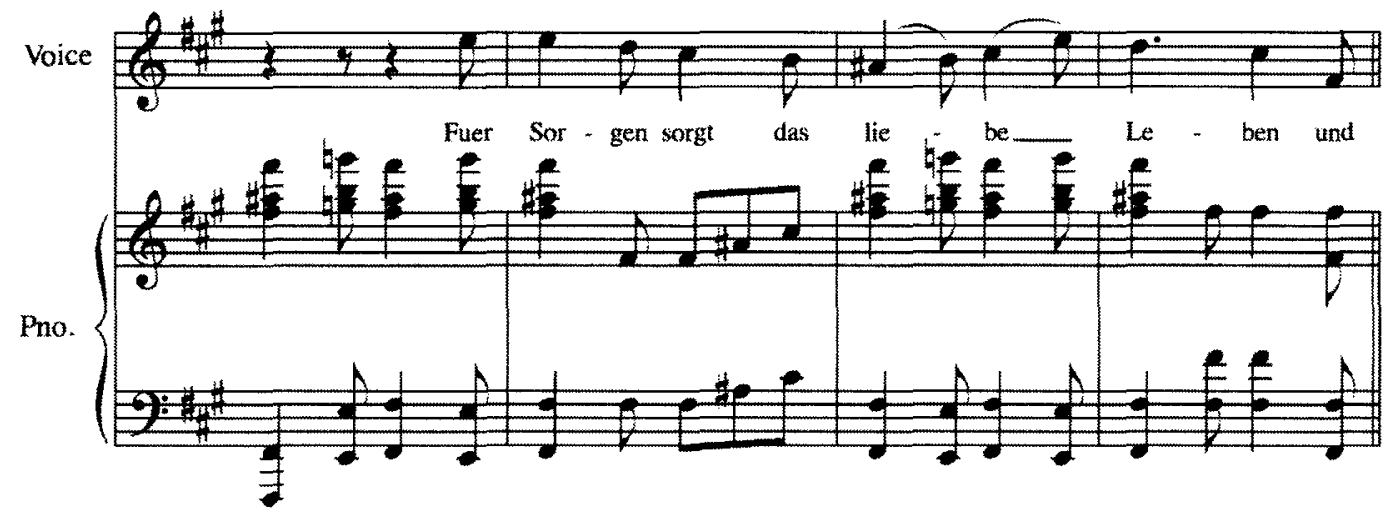

After the rest separating the two poems, the change in key, meter and tempo for "Da wird nicht mehr" is striking. Constant eighth notes in the piano emphasize the change of meter, and the jagged contour of the opening vocal line also distinguishes it from the relaxed final phrase of "Trunken müssen" to reflect the thematic difference between the two poems. While "Trunken müssen" reflects and enthusiastically supports the carefree qualities of wine, "Da wird nicht mehr" firmly reaffirms the laws against consuming alcohol and only reluctantly makes an allowance for the consumption of highquality wine. Goethe displays this change in perspective with a steady and unfailing trochaic meter, reflecting the unflagging opinion of the law. Wolf supports this in the musical characteristics described above.

As the poem "Da wird nich mehr" develops, Goethe accommodates the gradual tolerance for the consumption of good wine with a series of weakening final syllables within the AABBCC rhyme structure. The first two lines, describing the forbiddance of wine, both end with a harsh "-agt" syllable, while the second phrase tolerating the consumption of good wine ends with a less defined "-ein" syllable. The final two lines complete this transformation with an unstressed feminine ending on "-zer." While Wolf echoes the harsh "-agt" with an upward leap in the vocal line in measures 36 and 40, the 
vocal declamation in this poem is less varied than in "Trunken müssen." Several characteristics already discussed distinguish the opening lines, where Wolf also sets the opening (stressed) syllables of the lines on upbeats in a manner reminiscent of the opening of "Trunken müssen."

This opening to the vocal line is one way that Wolf provides some continuity between the two differing poetic sections. The positioning of stressed syllables on upbeats communicates a sense of interruption, which suits the change in theme between the two poems, but it also functions to bring the syllabic stress back to a trochaic pattern with the conventionally metered final words of each line.

The key of "Da wird nicht mehr" also provides some relationship between the two poems: the new key of A major is the relative major of the original F\# minor tonic, and "Trunken müssen" moves towards A major twice to foreshadow its later appearance (measures 9 and 20). "Da wird nicht mehr" also recalls the tonality of "Trunken müssen" by emphasizing $\mathrm{C} \#$ in measure 46 , the contrasting key and dominant of the previous poem, and moving towards F\# minor in measure 54 before the transition back to the opening theme. The use of keys from "Trunken müssen" in "Da wird nicht mehr" not only provides a transition back to the reprised opening, but also reflects the allowance of alcohol in the text of "Da wird nicht mehr."

In addition to key, Wolf also uses motives from "Trunken müssen" in "Da wird nicht mehr." These elements do more than unify the two poems into a single Lied; they mirror the developing tolerance for the consumption of alcohol throughout the poem. "Soll den doch getrunken sein" ("If you have to drink"), shown in Example 5, brings back the neighbor-tone oscillation from the second section of "Trunken müssen" and the 
octave interjections from the third section of the earlier poem. The proclamation to drink only the best wine in the passage that follows Example 5 features a descending replica of the main theme from "Trunken müssen" in the voice that is echoed briefly later in the piano accompaniment.

Example 5 "Trunken müssen wir alle sein!" mm. 42-45

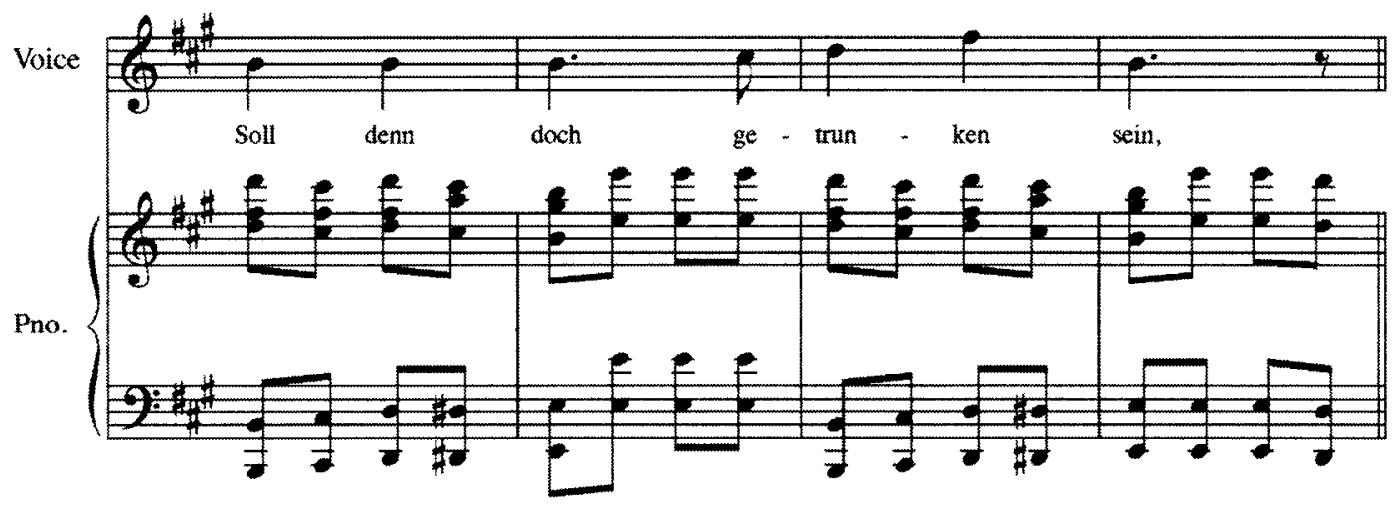

The piano accompaniment of the third section of "Da wird nicht mehr," shown in Example 6, is a variation in $2 / 4$ of the opening piano theme: a dotted-quarter/eighth-note pulse in the left hand and an inversion of the arch found in the neighbor-tone figure of the right hand. These elements segue into the repetition of the opening of "Trunken müssen" with newfound exuberance, building in a bacchic frenzy until the piano postlude collapses from the intensity.

Example 6 "Trunken müssen wir alle sein!" mm. 54-57

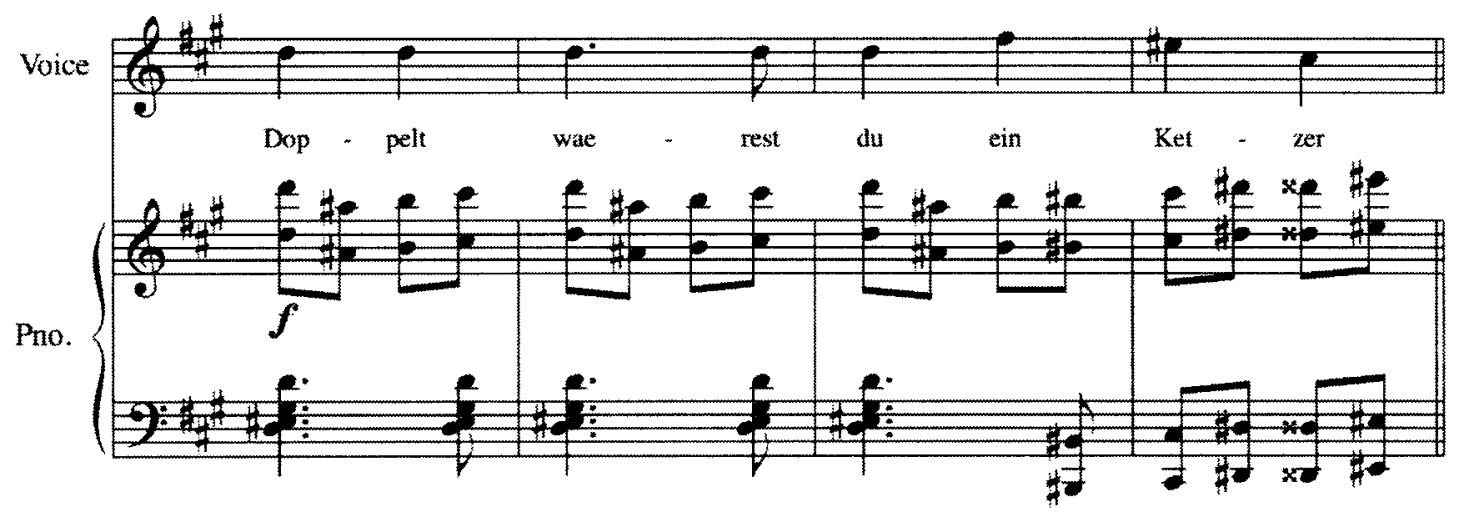


The ways in which Wolf binds the two poetic sections together reflect not only a musical connection between the two sections but also a thematic association between the two poems. The introduction of musical elements from "Trunken müssen" into " $\mathrm{Da}$ wird nicht mehr" portrays the growing tolerance for alcohol, but also reveals a narrative within the combination of poems. The exuberant love of alcohol exhibited by "Trunken müssen" (the opening is conspicuously marked "Bacchantisch," or "in the nature of a bacchanal") is silenced by the reminder of the prohibition of alcohol. However, at the first allowance for alcohol, the exuberance begins again and leads into an even more enthusiastic reprise.

The nature of the reprise reflects the ironic undertone of the entire Lied. "Da wird nicht mehr" allows the drinking of good wine because one would be "doubly a heretic for drinking bad wine." Yet the exuberance of "Trunken müssen" reflects the image of a drunken reveler rather than a refined intoxication on "the best wine." Wolf musically supports this idea when the motives from "Trunken müssen" appear in "Da wird nicht mehr" in a descending or inverted structure. These recurrences of motives can be seen by comparing Examples 5 and 6 with Example 3. Also, the placement of these motives reflects a sense of irony. The final, almost full repetition of the main theme in "Da wird nicht mehr" appears under the idea that drinking bad wine results in becoming a doubleheretic, shown above in Example 6. With this placement of the main theme, Wolf insinuates that the exuberance portrayed by the poet is not the exception for the consumption of good wine, but rather the double damnation of bad wine. 


\section{III. "So lang man nüchtern ist"}

So lang man nüchtern ist, Gefällt das Schlechte; Wie man getrunken hat, Wei $\beta$ man das Rechte; Nur ist das Überma $\beta$ Auch gleich zuhanden; Hafis, o lehre mich, Wie du's verstanden!

Denn meine Meinung ist Nicht übertrieben:

Wenn man nicht trinken kann, Soll man nicht lieben; Doch sollt ihr Trinker euch Nicht besser dünken, Wenn man nicht lieben kann, Soll man nicht trinken.
So long as one is sober, The inferior pleases; As one drinks, He knows what is right; Only excess is Also close at hand; Hafiz, o teach me, How you understand it!

For my opinion is Not exaggerated: If one cannot drink, One should not love. But you drinkers should not Think yourselves better, If one cannot love, One should not drink.

The first stanza of "So lang man nüchtern ist" addresses the problem of drinking wine: while drinking can promote higher consciousness, if one drinks mindlessly it can lead to excess. In the second stanza of text, the poet presents the understanding that mindful drinking means drinking with love in mind. Thus, only those who can love should drink wine. The view that love that accompanies the drinking of wine emphasizes the importance of Divine love in Sufi philosophy and distinguishes spiritual intoxication of such love from the banal drunkenness warned against in the first stanza.

Both stanzas of text contain two quatrains with an $\mathrm{ABCB}$ rhyme pattern. The first quatrain of each stanza presents an independent statement. In the first stanza the opening statement contrasts the all-pleasing nature of sobriety to the more refined understanding of the world through wine. In the second stanza, the opening statement is the poet's opinion that if one cannot drink one should not love. The second quatrain of each stanza responds with warnings of excess: drunken excess in the first stanza and an excessive 
feeling of pride on the part of drinkers in the second stanza. The close of the first stanza appeals to Hafiz as a spiritual guide for understanding the dilemma and the close of the second stanza states the speaker's vital solution of the problem: if one cannot love, one should not drink.

Wolf sets the two eight-line stanzas in a modified strophic form. The modifications to the strophic form are limited, and include a rhythmic alterations and the use of $\mathrm{E}$ minor to open the second strophe instead of the original A minor. Within each strophe, Wolf divides the two quatrains of text by adding a one-measure cadential extension to the vocal phrase. This cadential figure gives a sense of conclusion to the first quatrain of each stanza of text. A four-measure piano interlude and postlude similarly close each strophe of music.

The strophic form of the song sets each stanza of text parallel to the other and casts the solution in the same musical setting as the problem. Eric Sams noted that the musical repetition of the strophic form does not always fit the corresponding text and leaves "loose ends." ${ }^{2}$ However, these "loose ends" and the modifications to the second strophe highlight the relationship between the problem and the speaker's solution within the strophic structure.

A balanced form of parallel strophes that still yield a development from problem to answer is captured in the tonal development of the Lied, shown in Table 1. Overall, the song fits Deborah Stein's description of "directional tonality" in Wolf's songs: the Lied begins in one key, A minor, and concludes in a different key, D major. ${ }^{43}$

\footnotetext{
${ }^{42}$ Sams, 226-7.

${ }^{43}$ Deborah Stein, Hugo Wolf's Lieder and Extensions of Tonality (Ann Arbor, MI: UMI Research Press, 1985), 141-180.
} 
Table 1 Tonal organization in "So lang man nüchtern ist"

\begin{tabular}{|l|l|l|l|l|}
\hline & Phrase 1 & Phrase 2 & Phrase 3 & Phrase 4 \\
\hline First Strophe & a-B & G-B & g & D \\
\hline Second Strophe & e-f\# & G-B & g & D \\
\hline
\end{tabular}

The change in tonality between the opening and closing of the song reflects the overall development of the text as it moves from the consideration of problems to the presentation of a solution. There is also a parallel development in each of the strophes as the tonality moves from A minor and $\mathrm{E}$ minor to D major.

The piano interlude and postlude that punctuate the end of each strophe help define the overall tonal movement despite the movement to $\mathrm{D}$ major in each of the strophes. Both the interlude and postlude return through $\mathrm{E}$ major to A major before presenting a single D major chord, shown in Example 7. In the interlude, the D major chord appears on an upbeat. This weakens the emphasis on D major before the start of the second strophe. In the postlude, however, the D major chord is placed on the second beat and marked sforzando to conclude the song emphatically in D major.

Example 7 "So lang man nüchtern ist" mm. 20-21, 41-42

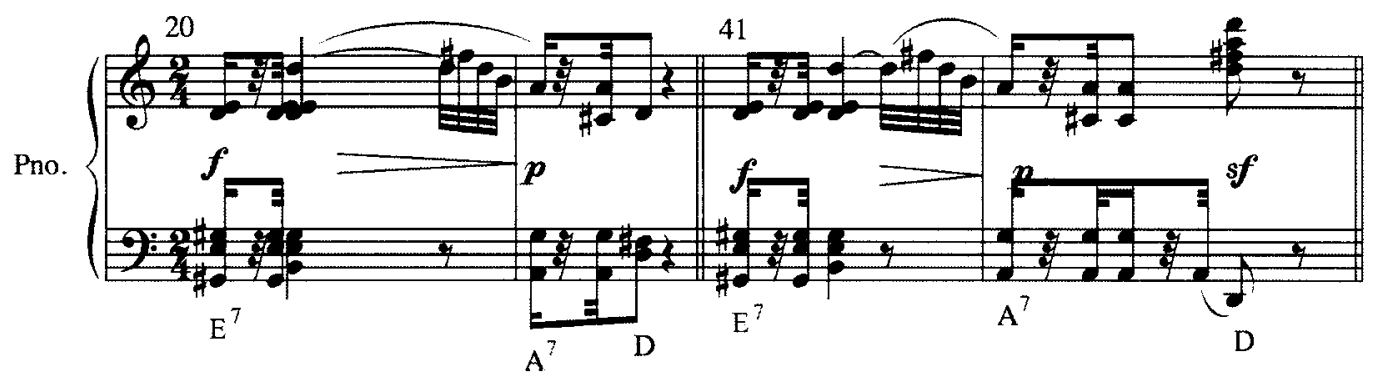

The use of E minor as the opening tonality of the second strophe is also significant to the tonal development of the song. Outwardly, the E minor reflects the 
change in perspective from problem to solution, but it also affects the perception of the harmonic construction of the rest of the strophe, shown above in Table 1. In the first strophe, the movement between tonal areas is jarring and not in a predictable pattern. Tonic A minor moves quickly to B major and references both $\mathrm{G}$ major and $\mathrm{G}$ minor. In the second stanza, E minor moves through $\mathrm{F} \#$ to $\mathrm{G}$, initiating a somewhat predictable movement by thirds that is only upset by reappearance of $\mathrm{G}$ minor in the third phrase. This modified tonal construction of the second strophe reflects the greater unity of the text of the second stanza and retraces the logic of the speaker's solution to the problem he noted in the first stanza.

The tonal construction of each strophe, aided by other musical elements, also reflects the specific text it accompanies. Wolf primarily uses the rhythmic and motivic construction of the piano line, dynamics, and vocal declamation to illustrate the message of each segment of text. The opening phrase, shown in Example 8, establishes these elements in the context of sobriety.

Example 8 "So lang man nüchtern ist" mm. 1-4 Sehr gemessen

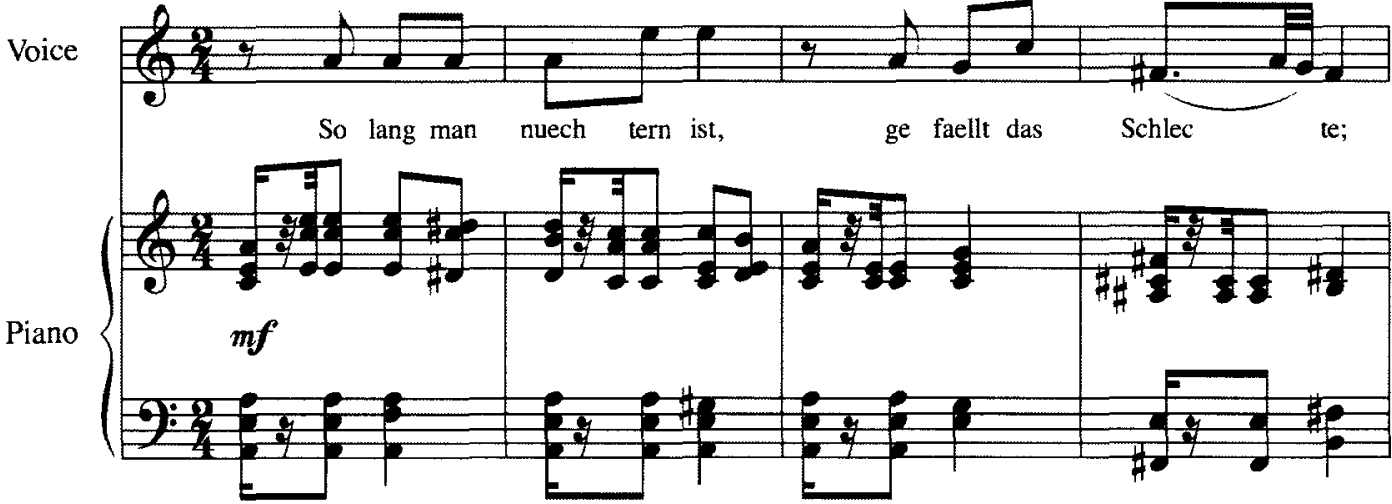

The piano accompaniment presents a strong metric pulse and rhythm based upon eighth-, sixteenth-, and thirty-second-note rhythms in a march-like style. Above the 
chordal pulse of the left hand of the piano, the upper voice contains a three-note motivic descent. In this opening line, two consecutive uses of the descending motive combine to cover a fifth, from $\mathrm{E}$ to $\mathrm{A}$. The vocal line is divided into two statements, each corresponding to a line of poetry, separated by an eighth-note rest, and the dynamic level stays as an unremarkable mezzo-forte.

All of these aspects, except the general march-like quality of the accompaniment, change in the second phrase, shown in Example 9. The descending motive of the previous phrase is paired with an eighth-sixteenth ascending motive, and consecutive appearances of the motive are separated by an octave.

Example 9 "So lang man nüchtern ist" mm. 5-8

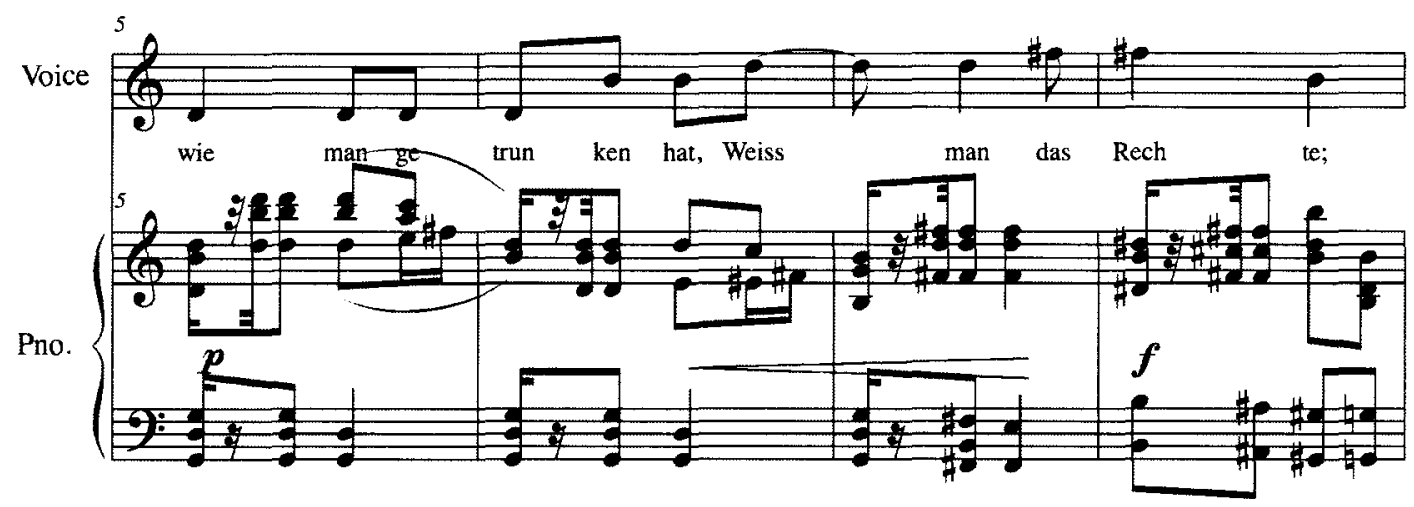

This new configuration of the descending motive reflects the fuller experience of life provided by wine with a larger range of the octave repetition and a stronger melodic presence. Eric Sams identified this combination of descending and ascending motives as a "love-motive," which reflects the importance love plays in intoxication according to the final conclusion of the poem. ${ }^{44}$ There is also a growth of dynamic, a crescendo from piano to forte, that contrasts the experience of wine to that of sobriety.

\footnotetext{
${ }^{44}$ Sams, 227.
} 
The vocal line of this phrase does not separate the two short lines of text it contains ("wie man getrunken hat/wei $\beta$ man das Rechte"). Instead, it begins the second line in the last measure of the previous line. Syncopation ties the two lines together into a single phrase. This combination of lines also contrasts sobriety and intoxication by providing unity and fluidity to the discussion of intoxication.

All three of these effects recur throughout the remainder of the song, and the second strophe noticeably eliminates the sobriety-related simplicity from the opening phrase. The use of dynamic contrast and syncopation to tie the vocal line together musically maintains the associations with wine. This mirrors the effect of the directional tonality in establishing the new perspective of the speaker's solution.

Wolf uses these musical reflections of intoxication to appropriate extremes in the warnings of excess. The dynamic level is increased to fortissimo, and the range and rhythmic profile of the piano accompaniment is also expanded. The shift to $\mathrm{G}$ minor is a reinterpretation of the $\mathrm{G}$ major of the second phrase. This musically connects the two warnings of excess with the preceding phrase: in the first stanza, the actual excessive use of wine, in the second stanza, exaggerating the importance of the drinker.

The interlude (Example 10) and postlude, then, provide a reflection on each strophe.

Example 10 "So lang man nüchtern ist" mm. 18-21

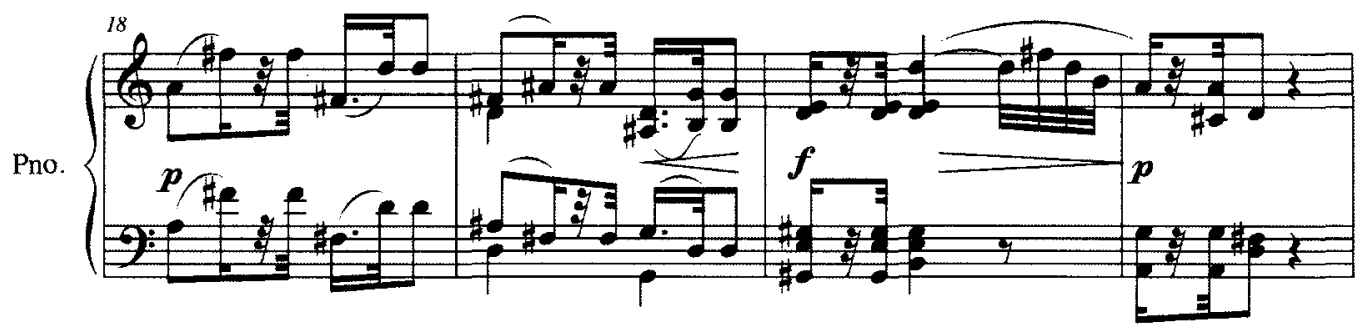


The upward leaps seem to pose a question before the cadential resolution, but Wolf also changes the rhythmic patterns of the song in an exploratory manner. Additionally, the postlude and interlude retrace the harmonic movements of the first stanza: D-G-B-A. The final D major chord of the piano postlude emphasizes the conclusion of the poem and the completion of the speaker's solution to the problem of drinking.

\section{IV. "Sie haben wegen der Trunkenheit"}

Sie haben wegen der Trunkenheit Vielfältig uns verklagt, Und haben von unsrer Trunkenheit Lange nicht genug gesagt. Gewöhnlich der Betrunkenheit Erliegt man, bis es tagt; Doch hat mich meine Betrunkenheit In der Nacht umher gejagt. Es ist die Liebestrunkenheit, Die mich erbärmlich plagt, Von Tag zu Nacht, von Nacht zu Tag In meinem Herzen zagt.

Dem Herzen, das in Trunkenheit Der Lieder schwillt und ragt, $\mathrm{Da} \beta$ keine nüchterne Trunkenheit Sich gleich zu heben wagt. Lieb-, Lied- und Weines Trunkenheit, Ob's nachtet oder tagt, Die göttlichste Betrunkenheit, Die mich entzückt und plagt.
They have because of our drunkenness Various things accused us, And have about our drunkenness Not long enough discussed. Ordinarily from drunkenness One succumbs to until it is day; But my drunkenness has In the night chased me around. It is love's drunkenness, That wretchedly torments me, From day to night, from night to day Makes my heart quaver.

The heart, that in drunkenness The song swells and rises, That no sober drunkenness Itself likewise dares to raise. Love, song and wine drunkenness, Whether night or dawn is breaking, The Godly drunkenness, Which delights and torments me.

In "Sie haben wegen der Trunkenheit," Goethe uses the meditative repetition of the ghazal form to explore the nature of drunkenness. Despite the numerous criticisms of drunkenness, the speaker insists that the critics' discussion is incomplete. The intoxication of the speaker, identified as love's drunkenness, is distinct from the typical drunkenness envisioned by critics. While typical intoxication ceases, the speaker's love- 
drunkenness is continuous and causes swelling in his heart unlike any other form of intoxication. The effects of love's drunkenness are explored and joined with the intoxication of song and wine to create a heavenly drunkenness that delights the speaker despite its torment.

Punctuation and different forms of the word "Trunkenheit" ("Trunkenheit," "Betrunkenheit" and "Liebestrunkenheit") divide the poem into five quatrains. Wolf affirms the quatrain divisions of the text through changes in the piano accompaniment and a separation of the lines of text in the voice with rests and/or the elimination of an anacrusis. However, Wolf still creates a slow development of the speaker's drunkenness that follows the repetitive ghazal form. Harry Seelig's analysis of "Sie haben wegen der Trunkenheit" notes how Wolf musically integrates all of the elements of the speaker's intoxication into "a culminating aesthetic experience. ${ }^{, 45}$ While Wolf achieves this, he also addresses vital omissions of the criticisms directed at the speaker and other drinkers.

Fittingly, the first two quatrains are the most musically independent portions of the song as they provide points of comparison and, for the most part, do not directly describe the speaker's drunkenness. The first quatrain begins the discussion about drunkenness by presenting the perceptions of intoxication that have already been discussed. Seelig notes that Wolf echoes some of these conventions with the continuously descending lines that evoke the descent into drunkenness and a grace-note tritone descent in the vocal line that "project the kind of awkward yodeling effect characteristic of a voice breaking under the influence of alcohol., ${ }^{46}$

\footnotetext{
${ }^{45}$ Seelig, "Ghazel Settings," 395.

${ }^{46}$ Ibid., 393.
} 
Wolf also echoes the discussion and the multiplicity of accusations against the drinkers by alternating the hands of the piano, as shown in Example 11. The alternating descents of the piano also correspond to the changes in the vocal line between the two notes of the tritone: the right hand always occurs with the upper note of the tritone while the left hand of the piano coincides with the lower note of the tritone.

Example 11 "Sie haben wegen der Trunkenheit" mm. 1-2

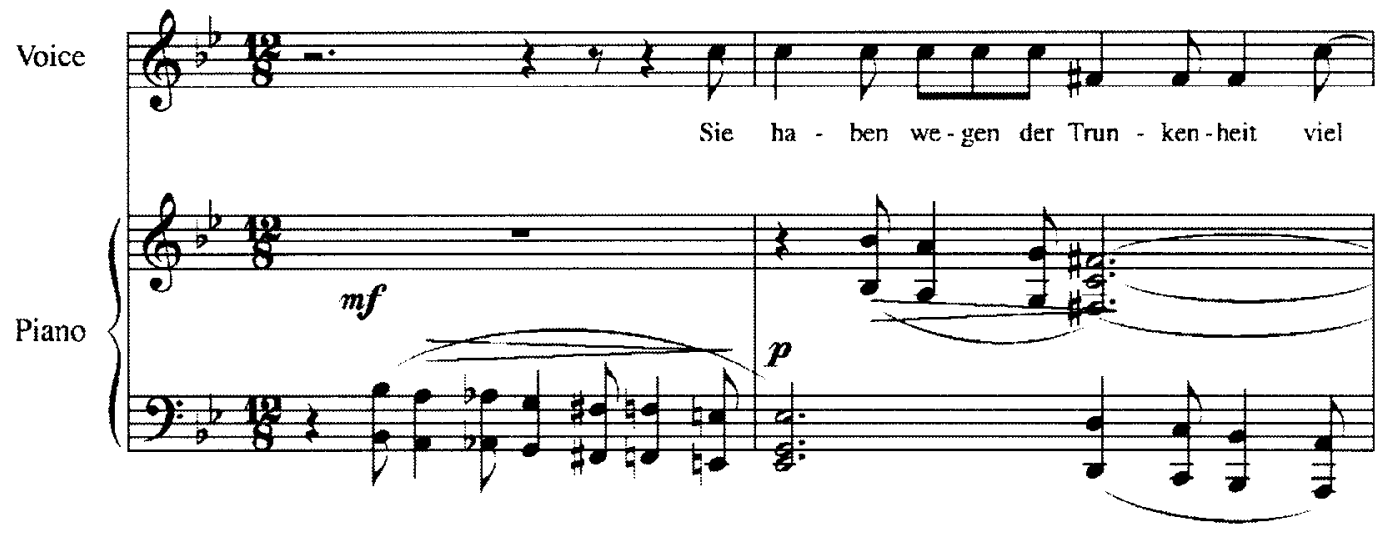

In the midst of the discussion of intoxication, Wolf uses conflicting tonal centers in the alternating lines of the piano to illustrate how there is an understanding missing from the criticism of intoxication. The descending lines in the left hand emphasize $E^{b}$ with descents to $E^{\mathfrak{b}}$ and $\mathrm{B}^{\mathrm{b}}$ major triads. The descent of the right hand to half cadences in G minor interrupts and prevents any tonicization. No G minor tonic appears to answer these cadences, and the tonal center of the song remains ambiguous throughout. An echo in the piano at the close of the first quatrain of text ponders the questions of a possible solution before the second quatrain explains the essential problem of the critics' discussion.

In the second quatrain, the alternation between the right and left hands in the piano is extended to two measures of each hand. The first two measures and the descent in the right hand correspond to the typical drunkenness that afflicts a person until dawn 
while a switch to the left hand occurs when the speaker describes his drunkenness. ${ }^{47}$ Shorter, layered descents and a greater harmonic motion distinguish the speaker's drunkenness that afflicts the speaker nonstop.

This last phrase leads to a central point in the poem - the identification of the speaker's drunkenness as love-drunkenness. In the poem, this third quatrain breaks the ghazal repetition of "Trunkenheit" by inserting the line "von Tag zu Nacht, von Nacht zu Tag" (from day to night, from night to day). At this point, the speaker is so overwhelmed by his love-intoxication that it overcomes the form of the poem. The first two measures of this quatrain (mm. 11-12, shown in Example 12) are pivotal to the remainder of the song.

Example 12 "Sie haben wegen der Trunkenheit" mm. 11-12

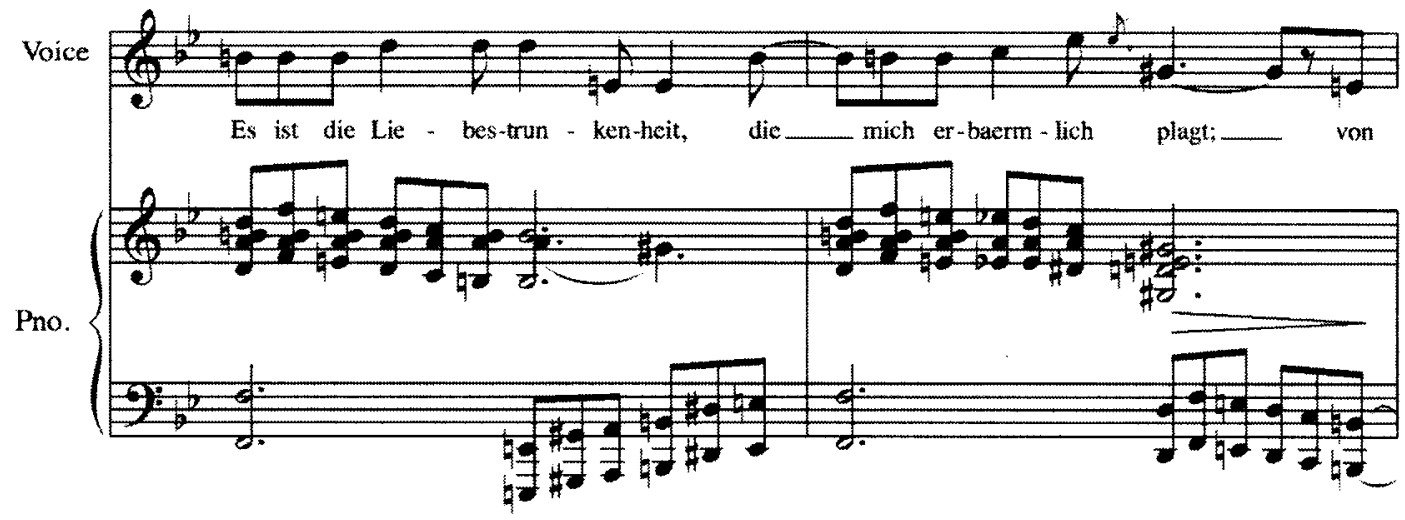

A steady eighth-note pulse is introduced for the first time and the left and right hands of the piano move from contrasting descending and ascending lines in measure 11

\footnotetext{
${ }^{47}$ Seelig associates the switch from the right to left hand between these two phrases as an approach by Wolf to reflect the "love-infected drunkenness literally [roaming] about in the nocturnal bass register of the pianist's left hand." He also notes the distinctions between the character of the two piano hands. "Ghazel Settings," 394.
} 
to imitating one another in measure $12 .{ }^{48}$ This leads to a more steadily active movement between the two hands of the piano for the rest of the song. The right hand maintains dotted-quarter note chords while the left hand moves in continuous eighth notes that are frequently tied to create gentle, insistent syncopation.

The musical depiction of the remainder of the symptoms of love's drunkenness uses changes in the flow of the left hand's constant eighth notes, tonal features in the chords in the right hand and the declamation of the vocal line to portray the aspects of love's drunkenness. For example, the left hand of the piano initially ascends in the fervor of recounting the endless effects of love's drunkenness in measure 13 but switches to descending motion in measure 15 at the image in the text of the quavering it causes in the speaker's heart. Additionally, the comparison of love's drunkenness to sober drunkenness is reinforced musically with the setting of "sober drunkenness" in a briefly stable tonality of A major with a lyrical melodic line that also operates with $\mathrm{A}$ as a tonal center. ${ }^{49}$ Wolf adds a final effect on the word "nüchterne" (sober) when the vocal line descends in parallel octaves with the left hand of the piano, providing a striking clarity in reference to sobriety.

Both the piano and the voice build to a climax in the final lines which describe the divine nature of the speaker's drunkenness and the speaker's delight in it. The climax occurs on the words "göttlischste Betrunkenheit" (Godly drunkenness) with the highest ranges and a brief passage in parallel octaves on the last syllable of "Betrunkenheit" to

\footnotetext{
${ }^{48}$ Seelig notes this eighth-note pulse as illustrating the transformation of the "passive rhythmic quality" of the eighth-quarter rhythm depicting typical drunkenness into love-drunkenness. Seelig also notices the mirroring of the two piano lines in measure 12 and describes the figure as portraying "swells of passion," though he does not comment on the relationship between the two hands. "Ghazel Settings," 394.

${ }^{49}$ Seelig also noted the "well-balanced, melodic and rhythmic shape" of this passage. "Ghazel Settings," 396.
} 
illustrate the exaltation of the divine drunkenness. Furthermore, $E^{b}$ major is recalled from the opening lines of the song and set as $\mathrm{V} / \mathrm{N}$ to cadence in $\mathrm{G}$ minor. At the highest moment of realization of the truth of intoxication, the two conflicting key areas of the opening are returned in a comprehensible order that at last provides a final tonic and close to the song.

\section{$\underline{\text { V. "Was in der Schenke" }}$}

Was in der Schenke waren heute Am frühsten Morgen für Tumulte! Der Wirt und Mädchen! Fackeln, Leute! Was gab's für Händel, für Insulte! Die Flöte klang, die Trommel scholl! Es war ein wüstes Wesen Doch bin ich, Lust und Liebe voll, Auch selbst dabei gewesen.

$\mathrm{Da} \beta$ ich von Sitte nichts gelernt, Darüber tadelt mich ein jeder; Doch blieb' ich weislich weit entfernt Vom Streit der Schulen und Katheder.
What sort of tumult there was Early this morning in the tavern! The landlord and girls! Torches, people! What kinds of arguments, insults there were! The flute sounded, the drum resounded! It was a wild being But I, full of delight and love, Also myself was present.

That I of custom nothing have learned, About it everyone scolds me; But I remain wisely far removed From disputes of schools and teachers.

There are three distinct sections in this poem. The first six lines describe the tumultuous scene in the bar with crowds and instruments. The next two lines come from the speaker himself and describe his presence at the tavern, full of delight and love. Collectively, these eight lines form the first stanza of text that divides through rhyme structure into two quatrains. Six of the eight lines conclude with unstressed endings that force a pause before the start of the next line and add to the instability and tumult of the poem itself. The final four lines of text are set apart from the preceding lines. Here, the speaker addresses the criticism that he has never learned proper manners and reaffirms his desire to stay away from scholastic debate. 
Wolf recreates the bar scene with large leaps in the vocal line and octaves moving quickly back and forth chromatically in the piano. Syncopation and the placement of syllabic stress on awkward and non-traditional beats recreate the disoriented sense of the conflict and also increase the performance difficulty. ${ }^{50}$ Wolf treats the song with a balladlike theatricality with a piano prelude, interlude and postlude that portray the tumultuous ambiance described in the vocal line.

Wolf musically separates the eight- and four-line divisions of the poem with an interlude in the piano. While the larger section of eight lines of text features a constant musical development, the musical setting of the last four lines of text is distinct and treated as a musical aside before the piano postlude returns to the music of the opening.

The continuity in the music outside of the final four lines of text comes from the use of the same basic musical elements of the piano accompaniment, which are reorganized to define each smaller section. These elements appear in the opening sequence under the first two lines of text, shown in Example 13. The texture thins from chords to open octaves, eventually reducing the texture to two notes before rebuilding with octaves and fifths to cadence on tonic. Movement is either chromatic or by leaps of fourths, fifths and tritones. Tones are repeated three times and offset from the $6 / 8$ metrical division of the pulse.

\footnotetext{
${ }^{50}$ Both Dietrich Fischer-Dieskau and Thomas Allen made rhythmic changes to the vocal line at measures 7 and 8 ("frühsten Morgen für Tumulte!") for their recorded performances.
} 
Example 13 "Was in der Schenke" mm. 5-8

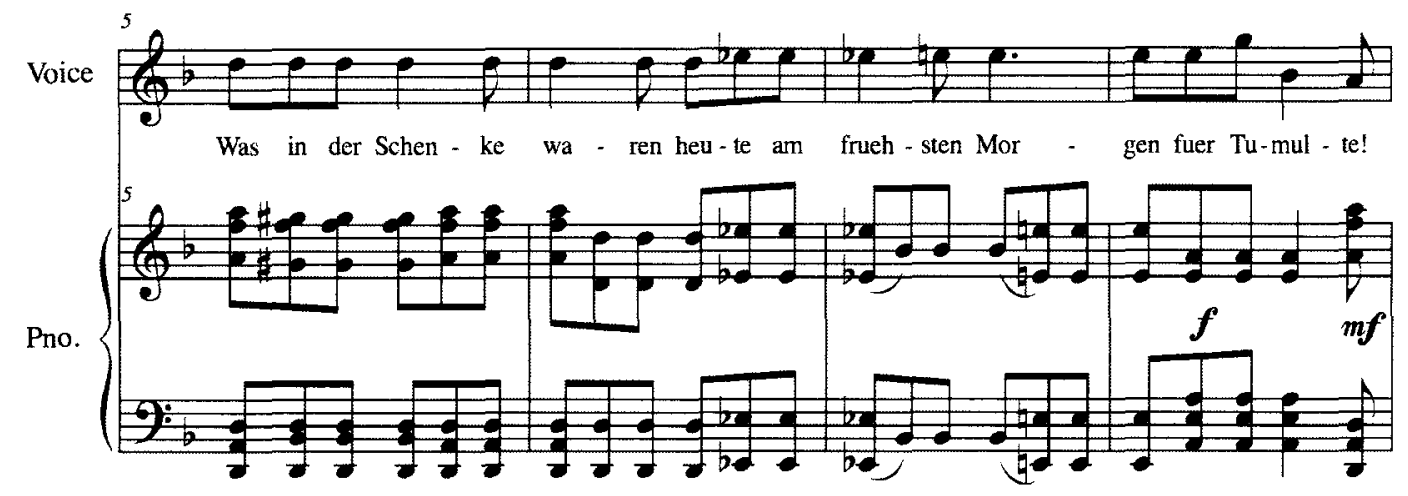

This pattern is repeated twice, once in the key of D minor and once in the key of E minor, under the first quatrain of text describing the tumult in the bar. The vocal line increases the excitement with expanding downward leaps and syncopation before it returns to a more traditional rhythmic pattern in the second quatrain of text.

The elements of the accompaniment are redistributed in this section of the Lied. The accompaniment in measures 27-30 ("Doch bin ich Lust und Liebe voll"), shown in Example 14, illustrates Wolf's recycling of thematic elements in a new section. The basic characteristics (chords, constant eighth notes, syncopation, contrasts of texture) remain the same, though Wolf replaces the gradual reduction of texture with a closer juxtaposition of the two textures.

Example 14 "Was in der Schenke" mm. 27-30

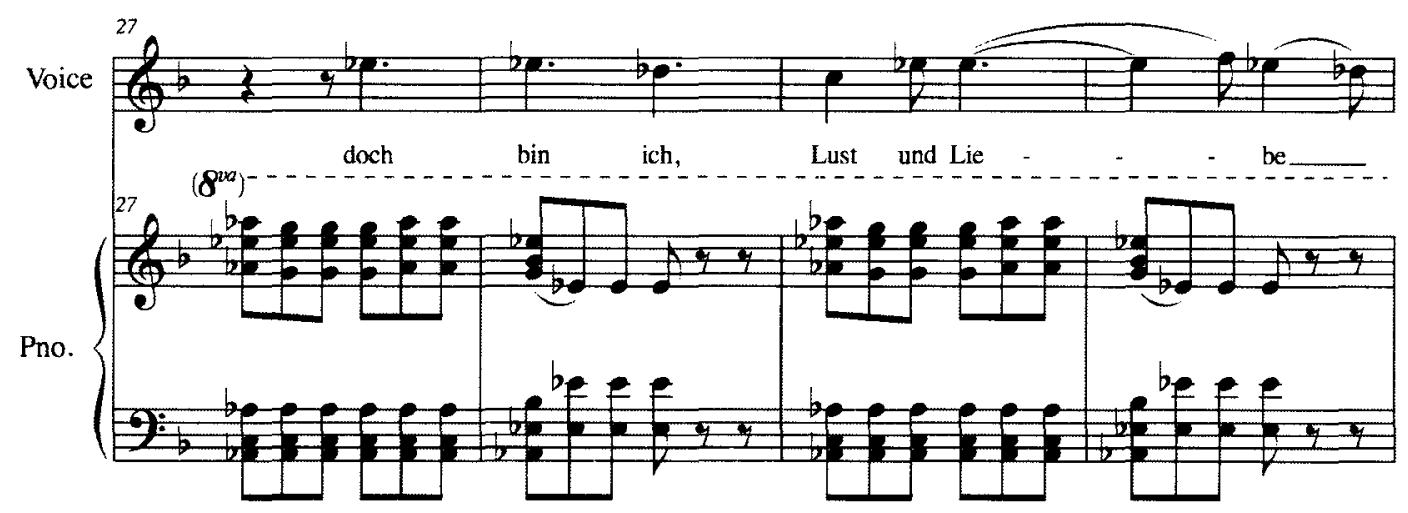


The piano interlude is governed by the contrast of chord and octave textures, ending on seven accented repetitions of $E$. Then the final four lines of text enter, distinguished from the preceding sections with an arch-shaped melodic line in the bass, shown in Example 15.

Example 15 "Was in der Schenke" mm. 47-50

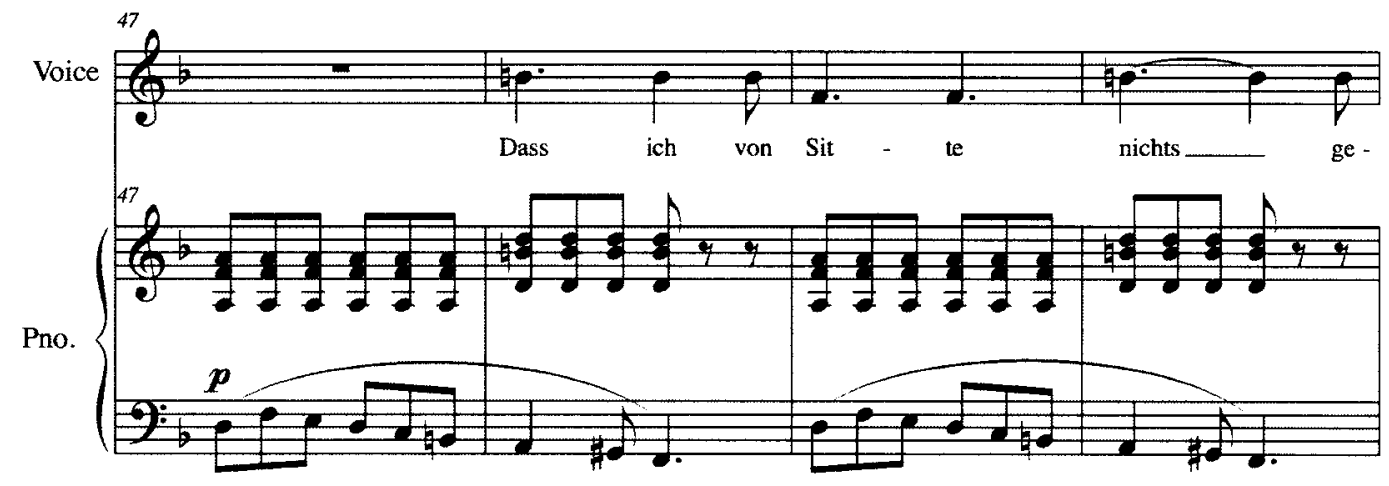

Eric Sams identifies melodic descents away from the vocal line as an evocation of separation or isolation in Wolf's songs. ${ }^{51}$ In this song this motive represents the speaker's separation from the intellectual arguments of scholars that culminates in an elaborate four-measure descent under the last line of text. The placement of the vocal and piano phrases out-of-phase adds to this sense of separation.

There is also a degree of separation between the speaker and the tumult in the tavern. In the text, the two lines that acknowledge the speaker's presence begin with the words "doch" (but) and "auch" (also). These words add a sense of detachment. The speaker was present, but he, unlike the remainder of the crowd in the bar, was full of delight and love. Though the piano accompaniment is based on elements from the bar scene, Wolf incorporates the sense of detachment. The key moves to $\mathrm{A}^{\mathrm{b}}$, a tritone away

\footnotetext{
${ }^{51}$ Sams, 25-6, 229.
} 
from tonic, and the piano line is an octave higher than the most of the preceding accompaniment.

The differentiation in the speaker's presence lies in his alignment with Sufi beliefs. He is full of delight and love, which symbolically distinguishes his experience as a spiritual one. The tavern becomes a place of learning, and the flutes and drums are ties to the Sufi traditions of singing poems to gain enlightenment beyond what intellectual debates can achieve.

The wisdom of the tavern is a matter of engaging experience. The syncopation, offset phrases and other musical effects provide a sense of insecure ecstasy that is quite different from the steady phrases of the confrontation with scholars shown in Example 15. The eighth notes fall in conventional groups of three and, though there is a phase shift between the voice and piano, it quickly becomes anticipated and predictable and lacks the excitement of the bar scene. This musical contrast between the debates of scholars and the world of the tavern is reinforced in the transition into the piano postlude which returns to the musical elements of the bar scene. Ultimately this contrast reveals the statement of the poet that scholars do not realize or appreciate the depth of knowledge that can be gained from such explorations and insinuates that the scholastic debates are not as relevant or revealing as what occurs in the tavern. 


\section{UNITY IN THE “SCHENKENBUCH” LIEDER}

The relationship among the five "Schenkenbuch" Lieder extends beyond their origin in the same source text. The combined exploration of the five songs provides explanation and instruction in the spiritual benefits of wine. "Ob der Koran von Ewigkeit sei?" introduces the concept of wine as a spiritual intoxicant. It states that wine allows a better understanding of God than conventional theological debate, represented by the dispute over the origin of the Koran. The two poems of "Trunken müssen wir alle sein!" follow and explore the justification for wine despite its forbiddance. In their exuberance, the poems display the possible excesses of drinking wine.

"So lang man nüchtern ist" provides a pivotal consideration of the problems presented by alcohol. It refers to the discussions of both "Ob der Koran von Ewigkeit sei?" and "Trunken müssen wir alle sein!" in the first stanza of text: the recognition that wine presents a more effective path to divine revelation drawing from the former and the fears of excess grounded in the latter. The speaker's personal belief resolves the dilemma by connecting wine and love: only those who can love should drink. This perspective allows the illumination provided by wine in "Ob der Koran von Ewigkeit sei?" yet avoids the excess by limiting the use of alcohol. This contrasts the mandate that all should drink in "Trunken müssen wir alle sein!" and likewise avoids overindulgence and banal drunkenness.

The connection between love and intoxication presented in the final stanza of "So lang man nüchtern ist" is further explained in "Sie haben wegen der Trunkenheit." The 
speaker recognizes that the true nature of intoxication has not been suitably explained and explains why intoxication caused by love is different, and therefore more enlightening and acceptable, than banal drunkenness. In "Was in der Schenke," the speaker aligns with the world of the tavern and wine and avoids the intellectual debates of scholars presented in the opening of "Ob der Koran von Ewigkeit sei?" While the world of the tavern is tumultuous, the speaker determines that he can learn more from the experience of life than from theological debates. This statement refers back to the content of "Ob der Koran von Ewigkeit sei?" and concludes the exploration of the subject.

Wolf outwardly ties the five songs together musically with similar meters, vocal ranges, declamation style, and harmonic language that provide the songs with a common musical identity. He also reincorporates musical elements such as form, tonal centers, textures and motives in each of the five songs to draw connections between similar opinions and perspectives. The self-referential nature of these musical elements creates a self-contained inter-related set of songs.

The forms of the "Schenkenbuch" Lieder reflect the focus and instructional role of each of the five songs, as shown in Table 2.

Table 2 Formal significance in the "Schenkenbuch" Lieder

\begin{tabular}{|l|l|l|l|l|}
\hline $\begin{array}{l}\text { "Ob der } \\
\text { Koran von } \\
\text { Ewigkeit } \\
\text { sei?" }\end{array}$ & $\begin{array}{l}\text { "Trunken } \\
\text { müssen wir alle } \\
\text { sein!" }\end{array}$ & $\begin{array}{l}\text { "So lang man } \\
\text { nüchtern ist" }\end{array}$ & $\begin{array}{l}\text { "Sie haben } \\
\text { wegen der } \\
\text { Trunkenheit" }\end{array}$ & "Was in der Schenke" \\
\hline Binary & Rounded binary & $\begin{array}{l}\text { Modified } \\
\text { Strophic }\end{array}$ & $\begin{array}{l}\text { Through- } \\
\text { composed }\end{array}$ & $\begin{array}{l}\text { Through-composed } \\
\text { (Coda) }\end{array}$ \\
\hline $\begin{array}{l}\text { Comparison of wine and } \\
\text { intellect in religious experience }\end{array}$ & $\begin{array}{l}\text { Connection of } \\
\text { wine and love }\end{array}$ & $\begin{array}{l}\text { Focus and elaboration of wine, love and } \\
\text { spiritual intoxication }\end{array}$ \\
\hline
\end{tabular}


In the first two songs of the "Schenkenbuch" Lieder, wine is contrasted with the religious experience of intellectual debate. Wolf reflects this contrast with binary forms in the two opening songs. The sectional division in "Ob der Koran von Ewigkeit sei?" follows the change in focus from the Koran's origins to the consideration of wine. The musical distinction between the two poems of "Trunken müssen wir alle sein!" corresponds to the discussion of wine independently and within Islamic law. Likewise, the focus on the combination of wine and love in "Sie haben wegen der Trunkenheit" and "Was in der Schenke" are reflected with through-composed forms. ${ }^{52}$

In a simplified view, the strophic form of "So lang man nüchtern ist" acts as a musical hinge between the binary and through-composed forms. This formal treatment models the relationship of the two stanzas of text to the songs surrounding it: the first stanza reflects the discussions of "Ob der Koran von Ewigkeit sei?" and "Trunken müssen wir alle sein!" while the second stanza looks forward to the focus on the nature of intoxication in "Sie haben wegen der Trunkenheit" and "Was in der Schenke."

This interpretation of formal design in the "Schenkenbuch" Lieder gives greater significance to Wolf's decision to conflate two poems in "Trunken müssen wir alle sein!" and use a strophic form for "So lang man nüchtern ist." The conflation of two poems in “Trunken müssen wir alle sein!" provides a more natural binary form that two individual settings would have lacked. ${ }^{53}$ Additionally, the use of strophic form in "So lang man

\footnotetext{
${ }^{52}$ The final quatrain of "Was in der Schenke" is a fairly independent section musically, but it can be interpreted here as a coda that reflects back to the conflict at the beginning of the song group. Its importance in providing closure to the development also justifies the way Wolf off-sets it from the rest of the text of the poem.

${ }^{53}$ The timeline of composition supports this idea: "Trunken müssen wir alle sein!" was composed on the final day (along with "Sie haben wegen der Trunkenheit") and therefore the basic outline of forms was already laid before Wolf began composition (the binary "Ob der Koran," strophic "So lang man nüchtern ist" and through-composed "Was in der Schenke" already composed). The closeness of composition of all
} 
nüchtern ist" gains artistic validity when it is considered in the context of all five songs. The parallel strophes of strophic form reflect the preceding and following Lieder as part of its role as the central song.

The harmonic design of the five songs also clarifies the exploration of wine in the "Schenkenbuch" Lieder. Wolf uses similar harmonic devices throughout the five songs, such as the weakening of tonic by casting it in inversion or as a dominant seventh chord, the use of the Neapolitan chord to modulate, and contrasts between major and minor modes of tonic. Additionally, the plagal relationship between A and D dominates not only the harmonic construction of the individual songs, but also the overall harmonic structure of the "Schenkenbuch" Lieder.

The plagal dichotomy between A and D is first introduced in "Ob der Koran von Ewigkeit sei?" D minor is featured as the contrasting key even though the relative major ( $\mathrm{C}$ major) that concludes the first phrase would be a more conventional choice. Instead, D minor appears as the new tonal center when the subject turns from the Koran to wine. Additionally, the Lied ends with a plagal cadence rather than an authentic cadence, reaffirming the connection between $\mathrm{D}$ and $\mathrm{A}$.

Similar contrasts between D and A appear in all of the "Schenkenbuch" Lieder except for "Trunken müssen wir alle sein!" A minor and D major outline the directional tonality in "So lang man nüchtern ist." Both D and A appear as brief tonal excursions in the wandering tonality of "Sie haben wegen der Trunkenheit." In "Was in der Schenke," the roles established in "Ob der Koran von Ewigkeit sei?" reverse as the song casts A as the dominant to the tonic $\mathrm{D}$ minor.

five songs, however, suggests the possibility that Wolf could have had the primary ideas for all of the poems in his mind before he began composition. 
Deborah Stein notes that in his Lieder Wolf uses the concept of "associative tonality" that was drawn from his study of the music of Wagner:

In the music of both Wagner and his follower Wolf, the appearance of associative tonal areas is not predicated upon a governing logic of tonal relations, but rather occurs in response to textual or dramatic exigencies. The resulting musical structures can be wholly unusual or idiosyncratic, and traditional tonal structures such as the tonic-dominant axis can be undermined or even replaced by nondominant harmonies such as third relations or harmonies of the plagal domain. In the use of associative tonality, the music is indeed mistress to the text, and the desire for musical continuity and coherence might well be superseded by the need for portraying poetic or dramatic tensions. ${ }^{54}$

The contrast of A and D in "Ob der Koran von Ewigkeit sei?" suggests an association between the two keys and the contrasts of wine and intellectual discussion. The key of A reflects the conventional faith of intellectual exploration drawn from the debate over the origin of the Koran while D suggests the more personal experience of spiritual intoxication through wine.

This association continues in "Trunken müssen wir alle sein!" where the second poem contemplating the prohibition of wine is in A major. Instead of associating the exuberant praise of intoxication with $\mathrm{D}$, Wolf chooses $\mathrm{F} \#$ minor for the first poem to differentiate between excessive drunkenness and spiritual intoxication. ${ }^{55}$ The A minor of "So lang man nüchtern ist" appears with the brief discussion of sobriety before wine is discussed and the song moves to D major. In the wandering tonality of "Sie haben wegen der Trunkenheit," A major appears in a moment of established tonality with the mention of "sober drunkenness" while D minor dominates the bar scene in "Was in der Schenke."

\footnotetext{
${ }^{54}$ Deborah Stein, Hugo Wolf's Lieder and Extensions of Tonality (Ann Arbor, MI: UMI Research Press, 1985), 44.

${ }^{55}$ Eric Sams points out that the F\# major that appears in "Trunken müssen wir alle sein!" is often used by Wolf to portray euphoria. Eric Sams, The Songs of Hugo Wolf (Bloomington, IN: Indiana University Press, 1992), 34-5, 225.
} 
Wolf's choice of a plagal relationship carries theoretical significance. The plagal relationship can easily reappear as a dominant-tonic relationship, otherwise representing that the experience of intoxication (D) can substitute for theological debate (A) as the center of faith. Wolf achieves this substitution over the course of the "Schenkenbuch" Lieder, as shown in Table 3. The final plagal cadence of "Ob der Koran von Ewigkeit sei?" (1) firmly establishes D as subsidiary to A. Yet the directional tonality of "So lang man nüchtern ist" (3) moves from A minor to D major and the concluding "Was in der Schenke" (5) features A as the supporting dominant to a tonic D minor.

Table 3 Tonal design in the "Schenkenbuch" Lieder

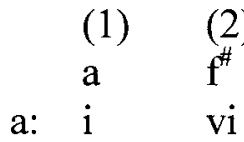
(3)

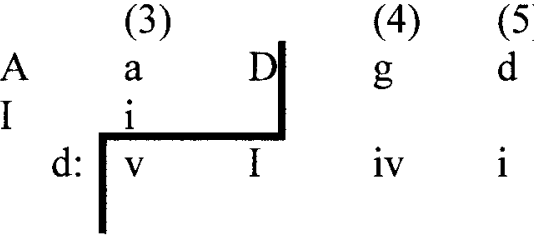

The use of "So lang man nüchtern ist" as a tonal pivot midway through the "Schenkenbuch" Lieder reflects the same change in focus represented in the formal design of the five songs. The consideration of conventional faith through intellectual discussion of the first two songs functions in keys related to A. The focus on wine and love in the last two songs similarly features keys related to D. As the central pivot, "So lang man nüchtern ist" reflects what precedes and follows with the directional tonality between $A$ and $D$.

In addition to the larger influence of key and form in the songs, Wolf also uses different musical elements to connect similar perspectives and concepts throughout the five songs. Among these is the contrast of chordal and octave textures in the accompaniment. The juxtaposition of these textures appears in all five the of 
"Schenkenbuch" Lieder as a means to underscore and differentiate ideas and emotions in the text. The effect is of a disagreement, protest or argument, as with the opening contrast in "Ob der Koran von Ewigkeit sei?" shown in Example 16.

Example 16 "Ob der Koran von Ewigkeit sei?" mm. 1-5

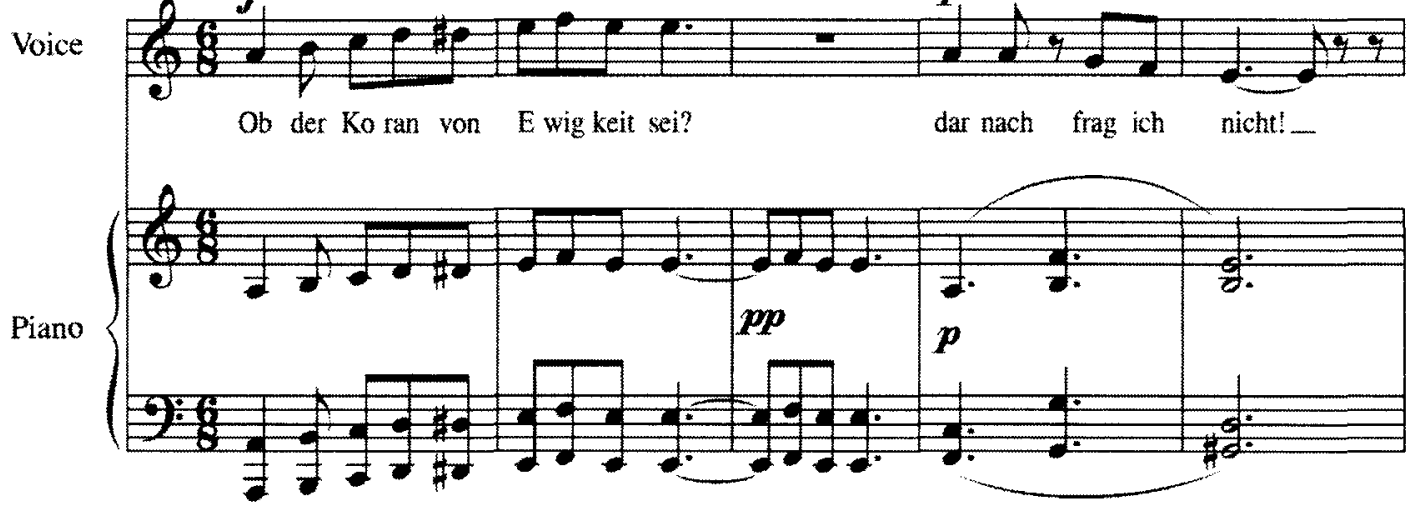

The contrast of texture in "Ob der Koran von Ewigkeit sei?" corresponds to the differences between intellectual debate and drinking. The thin texture of octaves represents intellectual discussion while the thicker texture of the chordal accompaniment introduces the perspective of the speaker. Eventually, the chordal texture evokes the enrichment that wine can provide. This meaningful treatment of texture has ties to Wolf's motivic devices explored by Eric Sams: "When the harmony remains unfilled, and only the so-called bare octave or bare fifth is employed...the effect is one of emptiness or transparency whether metaphorical or literal." ${ }^{, 56}$

"Trunken müssen wir alle sein!" interjects octave texture in the piano accompaniment in two sections, measures 21-24 and measures 42-45. Both passages correspond to text that brings disagreement from the opponents of wine: the claims that

\footnotetext{
${ }^{56}$ Sams, 33. Sams identifies the opening octaves of "Ob der Koran von Ewigkeit sei?" as a slightly different motive of questioning. Given the context of the octave/chord juxtaposition in the rest of the "Schenkenbuch" Lieder, I believe that Sams's attributions of open octaves and fifths as a signifier of emptiness is more apt.
} 
wine can transport the old back to youth and relieve men of all of their concerns in measures 21-24 and the decision to allow the drinking of the best wine in measures 42 45. The short octave passages in both cases evoke the sense of the protestations against the song's perspectives on wine.

Wolf foreshadows the second of these octave interjections in measure 41, shown in Example 17. This is a one-measure piano solo marked fortissimo that punctuates the space between the proclamation of wine's forbiddance and the exception for drinking the best wine. The texture is thin (octaves in each hand), but the right and left hand are in contrary motion.

Example 17 "Trunken müssen wir alle sein!" m. 41

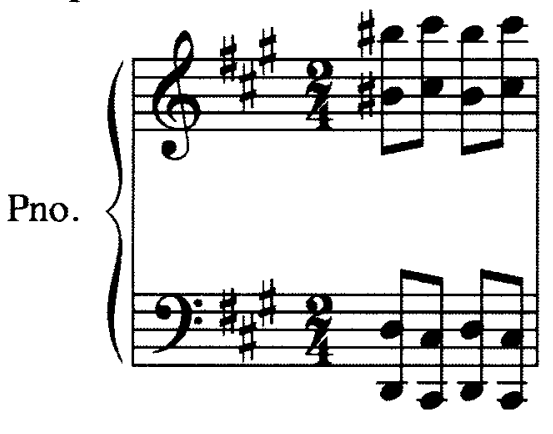

With its appearance immediately before the exception for the drinking the best wine, this contrary octave-motion reflects a divergence among the intellectuals: half are willing to consider an exception to allow wine while half are not. The only appearance of octave textures in "So lang man nüchtern ist" carries a similar sense of deliberation. The octave-chord contrast appears in the piano interlude and postlude to signify a retrospective look over the two views that had been considered in the first stanza of text.

There are only two brief appearances of the texture conflict in "Sie haben wegen der Trunkenheit," a short octave passage on the word "nüchterne" ("sober") in measure 18 and a more extensive parallel between voice and piano in measure 8 , shown in 
Example 18. Here, the voice descends with the right hand of the piano over the words "erliegt man, bis es tagt." The use of a parallel texture with a description of the usual drunkenness carries the association that this "usual" characterization of drunkenness is not as fulfilling as the love-drunkenness that affects the speaker.

Example 18 "Sie haben wegen der Trunkenheit" m. 8

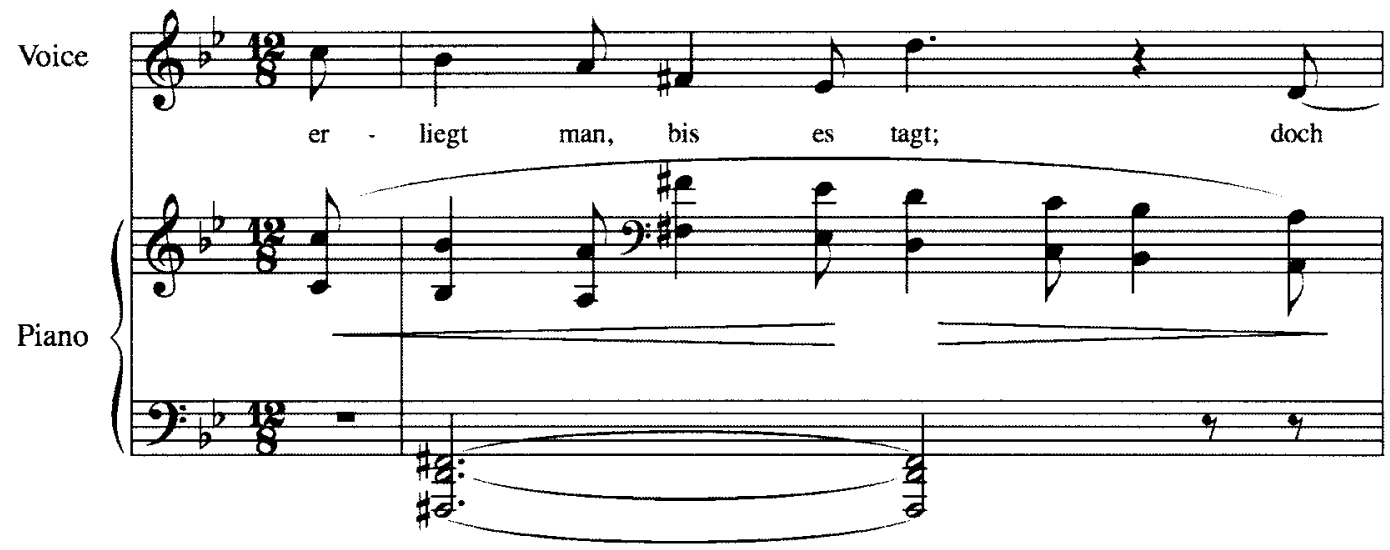

"Was in der Schenke" contains the largest number of textural juxtapositions to create the sense of tumult in the tavern. Here, though, the textual contrast is less symbolic than an illustration of the bar scene.

Wolf also uses other motivic references from "Ob der Koran von Ewigkeit sei?" throughout the "Schenkenbuch" Lieder to unify the five songs. The ascending opening of "Ob der Koran von Ewigkeit sei?" is inverted, possibly to represent a descent into drunkenness, in several of the songs. This descent is especially important to the piano accompaniment of "Sie haben wegen der Trunkenheit." The varied approaches to the piano descent mark the differences between the speaker's intoxication and banal drunkenness.

Additionally, the echoes in measure 3 and 8 of "Ob der Koran von Ewigkeit sei?" are referred to in "Trunken müssen wir alle sein!" and "Sie haben wegen der 
Trunkenheit." The main thematic idea of "Trunken müssen wir alle sein!" is derived from the neighbor tone in the echo while measure 6 of "Sie haben wegen der Trunkenheit" includes a modified echo of the vocal line. This echo, immediately following the line "on the subject of our drunkenness they have not said enough," attributes the incomplete discussion of intoxication to the same intellectuals featured in the opening of "Ob der Koran von Ewigkeit sei?"

One final reference links "Ob der Koran von Ewigkeit sei?" to the last section of "Was in der Schenke," in which the speaker distances himself from scholarly debates. The textual connection between these two sections, as already explained, provides a conclusion to the exploration of wine as the speaker aligns himself with Sufi philosophy. Wolf provides a musical link between these borders by reintroducing the syncopations of the postlude of "Ob der Koran von Ewigkeit sei?" into the piano accompaniment of "Was in der Schenke" at measures 53-55. 


\section{CONCLUSION}

The numerous motivic, harmonic and formal similarities that tie the five songs from "Das Schenkenbuch" together as well as the unified discussion of wine in the six poems that Wolf selected create a strong case for the consideration of the "Schenkenbuch" Lieder as an inter-related group of Lieder. The genius of Wolf"s settings is his ability to extract a unified message from "Das Schenkenbuch" and musically reflect not only the inner meaning of each song, but also its place in the overall discussion of wine and spiritual intoxication.

As has already been noted, this type of interrelationship is not unheard of in Wolf's large Lieder collections. Harry Seelig published a study arguing for such a unity in all seventeen of the West-östlicher Divan settings Wolf included in the GoetheLieder. ${ }^{57}$ While his study did not discuss the specific musical elements within the "Schenkenbuch" Lieder, Seelig set the "Schenkenbuch" Lieder and their portrayal of wine as a counter to the love poems of the "Buch Suleika" which follow in Wolf's Goethe-Lieder. Many of the general elements he discussed that link the Divan settings together also appear in the "Schenkenbuch" Lieder, such as an emphasis on the key of A and the use of leaps of fourth, fifths and sixths.

Even though the "Schenkenbuch" Lieder fall in the larger collection of the seventeen poems Wolf set from the West-östlicher Divan, their high level of

\footnotetext{
${ }^{57}$ Harry Seelig, "Hugo Wolf's Seventeen Divan-Setting: An Undiscovered Goethe-Cycle?" in Word and Music Studies: Essays on the Song Cycle and on Defining the Field: Proceedings of the Second International Conference on Word and Music Studies at Ann Arbor, MI, 1999, ed. Walter Bernhard and Werner Wolf (Amsterdam: Editions Rodopi, 2001), 183-209.
} 
interrelationships in terms of thematic development and the integration of wine as a symbol of spiritual intoxication set them apart from the remainder of the Divan settings. ${ }^{58}$ This is not to mean that they cannot fit into any formal organization among all of the Divan settings, but rather that the five "Schenkenbuch" Lieder can exist as an independent entity apart from the remainder of the Divan. The ultimate proof the strength of the interrelationship of the "Schenkenbuch" Lieder is that the elimination of any from the set would weaken the message and the effect of the songs as a whole.

\footnotetext{
${ }^{58}$ It is also worth noting that the settings from the "Buch Suleika" contain numerous reinterpretations of the same melodies between songs, something that separates the Suleika settings from "Das Schenkenbuch" and also the two songs from the "Buch des Sängers."
} 


\section{REFERENCES}

Adamec, Ludwig W. The A to Z of Islam. Lanham, MD: The Scarecrow Press, Inc., 2002.

Awn, Peter J. "Sufism." The Encyclopedia of Religion. Edited by Mircea Eliade, 14: 10422. New York: Macmillan Publishing Company, 1987.

Bahr, Hermann. Buch der Jugend. Vienna: H. Heller, 1908

Borg, Gert. "Arabic Literature." Encyclopedia of Islam and the Muslim World. Edited by Richard C. Martin, 63-63. New York: The Gale Group, Inc., 2004.

Bradley, Carol June. Index to Poetry in Music: A Guide to the Poetry Set as Solo Songs by 125 Major Composers. New York: Routledge, 2003.

Brody, Elaine and Robert A. Fowkes. The German Lied and Its Poetry. New York: New York University Press, 1971.

Ernst, Carl W. "Tasawwuf." Encyclopedia of Islam and the Muslim World. Edited by Richard C. Martin, 684-690. New York: The Gale Group, Inc., 2004.

Esposito, John L., ed. The Oxford Dictionary of Islam. Oxford: Oxford University Press, 2003.

Glauert, Amanda. Hugo Wolf and the Wagnerian Inheritance. Cambridge: Cambridge University Press, 1999.

Goethe, Johann Wolfgang von. West-östlicher Divan. In Goethes Werke. Band II, "Gedichte und Epen." Hamburg: Christian Wegner Verlag, 1962.

Hafiz. Fifty Poems of Hafiz. Translated and edited by Arthur J. Arberry. Cambridge: Cambridge University Press, 1962.

. The Gift: Poems by Hafiz the Great Sufi Master. Translated and edited by Daniel Landinsky. New York: Penguin Group, 1999.

Hallmark, Rufus. German Lieder in the Nineteenth Century. New York: Schirmer Books, 1996.

Lincoln, Bruce. "Beverages." The Encyclopedia of Religion. Edited by Mircea Eliade, 2: 119-22. New York: Macmillan Publishing Company, 1987. 
May, Yomb. "Goethe, Islam, and the Orient: The Impetus for and Mode of Intercultural Encounter in the West-östlicher Divan." Translated by James Hodkinson. In Encounters with Islam in German Literature and Culture, edited by James Hodkinson and Jeff Morrison, 89-107. Rochester, NY: Camden House, 2009.

Newman, Ernest. Hugo Wolf. New York: Dover Publications, Inc., 1966.

Parsons, James, ed. The Cambridge Companion to the Lied. Cambridge: Cambridge University Press, 2004.

Rahman, Fazlur. "Islam: An Overview." The Encyclopedia of Religion. Edited by Mircea Eliade, 7: 303-22. New York: Macmillan Publishing Company, 1987.

Renard, John. Historical Dictionary of Sufism. Lanham, MD: The Scarecrow Press, Inc., 2005.

Ritte, Hans. Das Trinklied in Deutschland und Schweden: Vergleichende Typologie der Motive. Bis 1800. Munich: Wilhelm Fink Verlag, 1973.

Roberts, James S. Drink, Temperance and the Working Class in Nineteenth-Century Germany. Boston: Allen \& Unwin, Inc., 1984.

Sams, Eric. The Songs of Hugo Wolf. Bloomington, IN: Indiana University Press, 1992.

Sams, Eric and Susan Youens. "Hugo Wolf." In The New Grove Dictionary of Music and Musicians, $2^{\text {nd }}$ ed., Edited by Stanley Sadie and John Tyrrell, 27: 463-501. New York: Grove Dictionaries, 2001.

Schumann, Elisabeth. German Song. New York: Chanticleer Press, 1948.

Schivelbusch, Wolfgang. Tastes of Paradies: A Social History of Spices, Stimulants, and Intoxicants. Translated by David Jacobson. New York: Pantheon Books, 1992.

Seelig, Harry. "Hugo Wolf's Ghazel Settings from Goethe's 'Schenkenbuch."' In The Romantic Tradition: German Literature and Music in the Nineteenth Century, edited by Gerald Chapple, Frederick Hall and Hans Schulte, 377-405. Lanham, MD: University Press of America, 1992.

."Hugo Wolf's Seventeen Divan-Settings. An Undiscovered Goethe-Cycle?" In Word and Music Studies: Essays on the Song Cycle and on Defining the Field: Proceedings of the Second International Conference on Word and Music Studies at Ann Arbor, MI, 1999, edited by Walter Bernhard and Werner Wolf, 183-209. Amsterdam: Editions Rodopi, 2001. 
Stein, Deborah J. Hugo Wolf's Lieder and Extensions of Tonality. Ann Arbor, MI: UMI Research Press, 1985.

Stein, Jack M. Poem and Music in the German Lied. Cambridge, MA: Harvard University Press, 1971.

Stierle, Karlheinz. "Furor Poeticus: Die vier Trunkenheiten in Goethes West-östlichem Divan." Poetica: Zeitschrift für Sprach- und Literaturwissenschaft 22, no. 3-4 (1990): 303-22.

Tlusty, B. Ann. Bacchus and Civic Order: The Culture of Drink in Early Modern Germany. Charlottesville, VA: University Press of Virginia, 2001.

Walker, Ernest. "Goethe and Some Composers." The Musical Times 73, no. 1072 (June 1932): 497-502.

Walker, Frank. Hugo Wolf: A Biography. New York: Knopf, 1952.

Weber, Mirjam. Der "wahre Poesie-Orient:" Eine Untersuchung zur OrientalismusTheorie Edward Saids am Beispiel von Goethes "West-östlichem Divan" und der Lyrik Heines. Weisbaden: Harrassowitz Verlag, 2001.

Wickens, G.M. "Hafiz Shirazi." The Encyclopedia of Religion. Edited by Mircea Eliade, 6:152-3. New York: Macmillan Publishing Company, 1987.

Williams, John R. "Goethe the Poet." In The Cambridge Companion to Goethe, edited by Leslie Sharpe, 42-65. Cambridge: Cambridge University Press, 2002.

. The Life of Goethe: A Critical Biography. Oxford: Blackwell Publishers, 1998.

Wolf, Hugo. Letters to Melanie Köchert. Translated and edited by Louise McClelland Urban. Madison, WI: University of Wisonsin Press, 1991.

. Goethe-Lieder. Band IV. Frankfurt: C.F. Peters.

Youens, Susan. Hugo Wolf: The Vocal Music. Princeton, NJ: Princeton University Press, 1992. 


\section{CURRICULUM VITAE}

Theresa Luebbers Cole

tklcole@gmail.com

Education:

University of Louisville

May 2011

Master of Music, Music History

Murray State University

May 2007

Bachelor of Music, Music Education

Teaching Experience:

Graduate Teaching Assistant, University of Louisville

Graduate Assistant, Murray State University

Honors and Awards:

Rey M. Longyear Student Paper Award, South-Central Chapter, American Musicological Society, 2011

Professional Memberships:

American Musicological Society

Sigma Alpha Iota Professional Women's Music Fraternity

Papers Presented:

University of Louisville Graduate Research Symposium, 2011:

"Two Poets and a Composer Meet in a Bar: Thematic Unity in Hugo Wolf's 'Schenkenbuch' Settings"

American Musicological Society South-Central Chapter Annual Meeting, 2011:

"Poetic Alteration in Hugo Wolf's 'Trunken müssen wir alle sein!"”

Murray State University Scholars Week, 2009:

"Back from the Underworld: The Recurrence in Opera of the Orpheus Myth" 